Review

\title{
Fermentation Strategies for Production of Pharmaceutical Terpenoids in Engineered Yeast
}

\author{
Erdem Carsanba ${ }^{1,2}$, Manuela Pintado ${ }^{2}$ and Carla Oliveira ${ }^{2, *}$ \\ 1 Amyris BioProducts Portugal, Unipessoal, Lda. Rua Diogo Botelho 1327, 4169-005 Porto, Portugal; \\ carsanba@amyris.com \\ 2 CBQF-Centro de Biotecnologia e Química Fina-Laboratório Associado, Universidade Católica Portuguesa, \\ Escola Superior de Biotecnologia, Rua Diogo Botelho 1327, 4169-005 Porto, Portugal; mpintado@porto.ucp.pt \\ * Correspondence: cmoliveira@porto.ucp.pt
}

Citation: Carsanba, E.; Pintado, M.; Oliveira, C. Fermentation Strategies for Production of Pharmaceutical Terpenoids in Engineered Yeast. Pharmaceuticals 2021, 14, 295. https:// doi.org/10.3390/ph14040295

Academic Editor:

Marialuigia Fantacuzzi

Received: 9 March 2021

Accepted: 24 March 2021

Published: 26 March 2021

Publisher's Note: MDPI stays neutral with regard to jurisdictional claims in published maps and institutional affiliations.

Copyright: (c) 2021 by the authors. Licensee MDPI, Basel, Switzerland. This article is an open access article distributed under the terms and conditions of the Creative Commons Attribution (CC BY) license (https:// creativecommons.org/licenses/by/ $4.0 /)$.

\begin{abstract}
Terpenoids, also known as isoprenoids, are a broad and diverse class of plant natural products with significant industrial and pharmaceutical importance. Many of these natural products have antitumor, anti-inflammatory, antibacterial, antiviral, and antimalarial effects, support transdermal absorption, prevent and treat cardiovascular diseases, and have hypoglycemic activities. Production of these compounds are generally carried out through extraction from their natural sources or chemical synthesis. However, these processes are generally unsustainable, produce low yield, and result in wasting of substantial resources, most of them limited. Microbial production of terpenoids provides a sustainable and environment-friendly alternative. In recent years, the yeast Saccharomyces cerevisiae has become a suitable cell factory for industrial terpenoid biosynthesis due to developments in omics studies (genomics, transcriptomics, metabolomics, proteomics), and mathematical modeling. Besides that, fermentation development has a significant importance on achieving high titer, yield, and productivity (TYP) of these compounds. Up to now, there have been many studies and reviews reporting metabolic strategies for terpene biosynthesis. However, fermentation strategies have not been yet comprehensively discussed in the literature. This review summarizes recent studies of recombinant production of pharmaceutically important terpenoids by engineered yeast, S. cerevisiae, with special focus on fermentation strategies to increase TYP in order to meet industrial demands to feed the pharmaceutical market. Factors affecting recombinant terpenoids production are reviewed (strain design and fermentation parameters) and types of fermentation process (batch, fed-batch, and continuous) are discussed.
\end{abstract}

Keywords: terpenoids; S. cerevisiae; pharmaceutics; fermentation; fed-batch

\section{Introduction}

Terpenoids, also known as isoprenoids or terpenes, constitute one of the largest chemically and structurally diverse group of natural products with over 80,000 members in a widespread family (currently stated in the Dictionary of Natural Products database, http:/ / dnp.chemnetbase.com, accessed on 26 March 2021) [1-4]. Although the majority of terpenoids are predominantly present in plants, other organisms such as bacteria, fungi, insects, and animals contain them as well [5]. Their essential biological functions can be counted as the regulation of cell growth and defense in plants (e.g., tocopherol, gibberellin), and intracellular electron transport, glycoproteins biosynthesis and cell membranes formation in animals (e.g., cholesterol) [6]. Owing to their structural variety, there exist diverse terpenoid activities, such as mediating symbiotic or antagonistic interactions between organisms to electron transfer, protein prenylation, or contribution to membrane fluidity, which make these compounds highly useful to be applied in various industries: food, cosmetics, fine chemistry, pharmacy, agriculture, and biofuel [5].

Terpenoids are formed from several isoprene (2-methylbuta-1,3-diene; IUPAC 1997) $\left(\mathrm{CH}_{2}=\mathrm{C}\left(\mathrm{CH}_{3}\right)-\mathrm{CH}=\mathrm{CH}_{2}\right)$ structural units (or building blocks) synthesized from meval- 
onate (MVA) or 2-C-methyl-d-erythritol 4-phosphate (MEP) (which is also known as the non-mevalonate) pathway [2,3]. Through the condensation reactions of these units, several large and more complex compounds are produced. According to the number of C5 isoprene units, terpenoids are mainly classified in hemiterpenoid (C5), monoterpenoid (C10), sesquiterpenoid (C15), diterpenoid (C20), triterpenoid (C30), tetraterpenoid (C40), and polyterpenoid $(C>40)[2,3,6]$. Terpenoids are mostly formed through continuous addition of head to tail manner of building blocks, which are isoprene diphosphate (IPP) and dimethylallyl diphosphate (DMAPP). For instance, the precursor of monoterpenoids, geranyl diphosphate (GPP), is produced by head to tail condensation of these two building blocks. Later, addition of IPP leads to the formation of farnesyl diphosphate (FPP) and geranylgeranyl diphosphate (GGPP), which are precursors of sesquiterpenoid and diterpenoid. On the other hand, head to head condensation of two molecules of FPP and GGPP, respectively, forms squalene and phytoene, the precursors of triterpenoid and tetraterpenoid [6,7] (Figure 1). Furthermore, these precursors are exposed to oxidation, by cytochrome P450 oxygenases, and glycosylation, by glycosyltransferases to form various terpenoids. In addition, prenyltransferases concatenates isoprene-derived precursors to fatty acid-derived precursor to synthase complex terpenoids or meroterpenoids, which consist of the medically important compounds, cannabinoids [2].

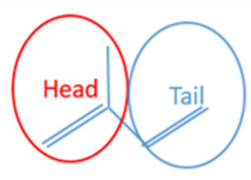

Isoprene

A) Head to tail condensation:

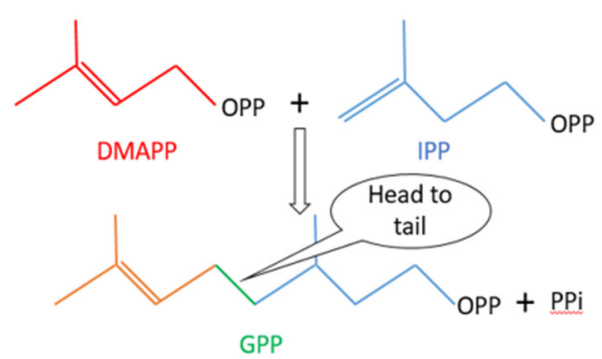

B) Tail to tail condensation:

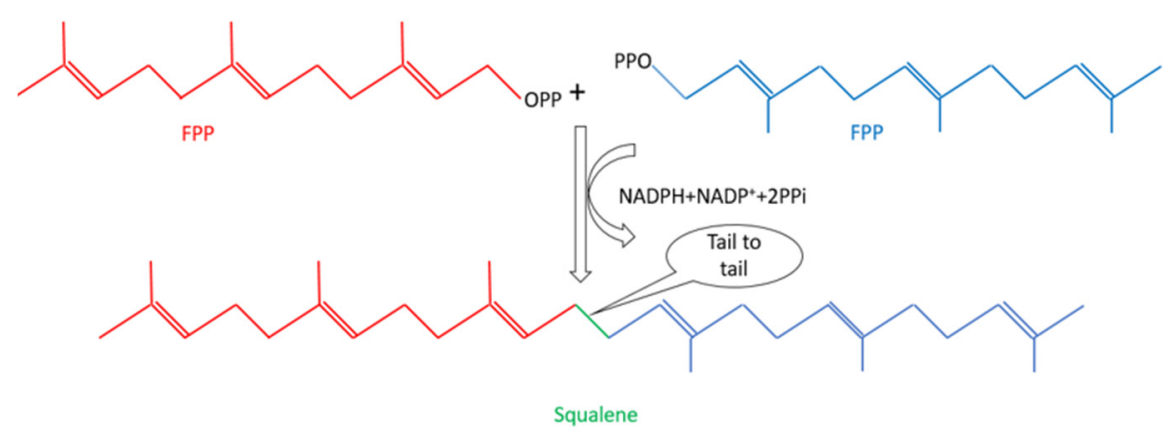

Figure 1. The condensation reactions of terpenoid biosynthesis: (A) Head to tail condensation and (B) Tail to tail condensation (Adapted from [7]).

From early ancient times up to now, terpenoids have been playing important roles in many medical treatments as pharmaceuticals with diverse biomedical activities, such as antimalarial, anticancer, anti-inflammatory, antibacterial, antiviral, hypoglycemic, preventing and treating cardiovascular diseases, and promoting the transdermal absorption. 
Besides that, they can have insecticidal, immunomodulatory, antioxidant, antiaging, and neuroprotective effects $[2,3,8,9]$. They are usually produced from natural resources through extraction or by chemical synthesis, but the obtained yields are generally low due to inherently low level of target compound and the necessity of complex extraction and chemical synthesis methods, which are commercially infeasible [10]. In most cases, the natural production method, extracting terpenoids from original sources (e.g., taxol from yew tree and artemisinin from the plant Artemisia annua) generally fails in terms of quality and supply management due to seasonal and geographical alterations [5]. In addition, plant engineering for terpenoid production is difficult and complex due to tissue specific expression and loss of volatile products by evaporation, and productivity and yields are very low [11]. Due to these limitations, microbial production of terpenoids has received increasing attention, since production of these compounds at large scale fermentation by engineered microorganisms offers a promising higher yield, batch-to-batch consistence, lower production cost, and more sustainability.

Among terpenoids, the sesquieterpenoid artemisinin have been often used as an antimalarial drug and the diterpenoid taxol (paclitaxel) have been developed to be an important anticancer chemotherapy drug for many years [12]. Semi-synthetic artemisinin is currently manufactured by the French pharmaceutical company Sanofi, using engineered Saccharomyces cerevisiae strain developed by Amyris [13], which is a very important example of microbial industrial production of terpenoids. However, the same success has not been yet achieved for paclitaxel due to the complexity of its synthesis pathway, which is still unclear and further studies are required to fully elucidate it [14]. So far, the highest recorded titer of oxygenated taxanes has reached up to $570 \mathrm{mg} / \mathrm{L}$ in engineered Escherichia coli by optimizing the P450 expression of taxanes and other related enzymes [15].

For centuries, the baker's yeast, $S$. cerevisiae, has been mainly used in the industrial production of alcoholic beverages (wine, beer, and distilled spirits), bakery products, and bioethanol. However, with the latest developments in synthetic biology, it became one of the most widely industrially used cell factory in the microbial production of a wide variety of products, such as alcohols, organic acids, amino acids, enzymes, therapeutic proteins, chemicals, and metabolites [16]. Among them, for example, biopharmaceutical recombinant peptide hormone, insulin, has been produced by genetically engineered $S$. cerevisiae strains for many years. Many pharmaceutical companies have chosen this yeast as the most suited host organism to produce a large variety of recombinant products due to its well-known genetics, physiology, biochemistry, and genetic engineering background, the availability of genetic tools, and the suitability of dense and large scale fermentation [16-18].

In the same line, $S$. cerevisiae has emerged as a model organism for the production of terpenoids since it has many additional advantages other than mentioned above, such as generally regarded as safe (GRAS) status, high genetic tractability, ease of manipulation, possessing universal endogenous MVA pathway, ability to express eukaryotic cytochrome P450 enzymes, robustness, relatively absence of secondary metabolites, high sugar catabolic, fast growth rate, and high tolerance against harsh industrial conditions [7,19-22].

Besides S. cerevisiae, other microorganisms have been explored for terpenoids production. Among them, E. coli has the most restrict chassis, since its produces natively limited amounts of terpenoids (e.g., quinones) and, therefore, the improvement of MEP pathway by engineering enzymes for IPP and DMAPP synthesis, or the introduction of heterologous MVA pathway, is required [23]. In contrast, S. cerevisiae has an endogenous MVA pathway, producing high amounts of ergosterol and native cytochrome P450 enzymes for the modification of terpenoids skeleton. Nonconventional yeast Yarrowia lipolytica has been also considered as a suitable yeast to synthesize terpenoids due to its capacity to produce large amount of acetyl-CoA, the initial substrate of the MVA pathway [23]. In addition, carotenogenic yeast Rhodosporidium toruloides can naturally accumulate several carotenoids (C40 terpenoids), indicating that it might have high carbon flux through MVA pathway, ensuring pools of intermediates for producing diverse types of terpenes [24]. This yeast can metabolize efficiently both xylose and glucose, and tolerates high osmotic stress, 
enabling the use of lignocellulosic hydrolysates as feedstock in contrast to S. cerevisiae [24]. Cyanobacteria have also the potential to produce sustainable terpenoids using light and $\mathrm{CO}_{2}$ instead of sugar feedstocks. However, terpenoids titer and productivity obtained are still below industrial levels and further studies to overcome the barriers for efficient conversion of $\mathrm{CO}_{2}$ to terpenoids are needed [25].

Overall, S. cerevisiae has as main advantage over E. coli and cyanobacteria hosts its intrinsic MVA pathway, and the disadvantage over Rhodosporidium toruloides host the incapacity of using directly lignocellulosic hydrolysates as feedstock. Nevertheless, S. cerevisiae is quite superior to the other microorganisms in respect to higher process robustness, fermentation capacity, plenty of available genetic tools in pathway engineering and genome editing, and proven capacity to attain industrial levels of relevant terpenoids [23].

To date, there has been a strong effort for terpenoid biosynthesis through metabolic engineering of microbes, however, production levels are at the $\mathrm{mg} / \mathrm{L}$ scale in scientific literature, which are generally too low and commercially insufficient. Economically meaningful metrics of titer ( $g$ product per L broth), yield (g product per g substrate), and productivity (g product per L broth per hour) should be provided for industrial production [11]. Fermentation development at scale has a crucial importance to improve terpenoids production. For example, Amyris has reached titers of more than $130 \mathrm{~g} / \mathrm{L}$ of $\beta$-farnesene and $25 \mathrm{~g} / \mathrm{L}$ of artemisinic acid (precursor of artemisinin, antimalarial drug) from sugar cane feedstock in engineered yeast $S$. cerevisiae through optimized fed-batch fermentation [26-28]. Fermentation strategies can increase productivity and reduce the cost of production via improving medium composition, optimizing physicochemical conditions, and applying efficient downstream processing. However, a complete overview of the current approaches for obtaining terpenes relevant for the field of pharmaceuticals by yeast fermentation has not yet been reviewed in the literature. Therefore, this review details the production of pharmaceutical terpenoids by engineered yeast $S$. cerevisiae and focuses attention on fermentation strategies to improve their production scale. Different fermentation factors and processes are discussed.

\section{Pharmaceutical Terpenoids}

A vast number of terpenoids have been widely used in medicine and medical sciences to prevent and treat many diseases due to their pharmaceutically bioactive properties. Their wide pharmaceutic effects and medical functions have already been extensively revised in the literature (see reviews: $[3,7-9,14,29-31]$. Some of the pharmaceutical terpenoids currently used in medicine and produced via biotechnological approaches are presented in Table 1.

Table 1. Pharmaceutical activities of common terpenoids produced by biotechnological means.

\begin{tabular}{|c|c|c|c|}
\hline Classification of Terpene & Terpene Name & Pharmaceutical Function & References \\
\hline Monoterpene & $\begin{array}{l}\text { Perillyl alcohol } \\
\text { Geraniol } \\
\text { D-limonene } \\
\text { Menthol } \\
\text { Sabinene }\end{array}$ & $\begin{array}{c}\text { Anticancer } \\
\text { Anticancer } \\
\text { Anticancer, transdermal absorption of drugs } \\
\text { Antimicrobial, transdermal absorption of drugs } \\
\text { Antimicrobial }\end{array}$ & {$[3]$} \\
\hline Sesquiterpene & $\begin{array}{l}\text { Artemisinin and its derivatives } \\
\text { Patchoulol }\end{array}$ & $\begin{array}{l}\text { Antimalarial, anticancer, antibacterial, antiviral activities and } \\
\text { hypoglycemic effect } \\
\text { Antibacterial activity }\end{array}$ & {$[3,32]$} \\
\hline Diterpene & Paclitaxel & $\begin{array}{l}\text { Anti-ovarian, breast, colorectal, head and neck cancers, } \\
\text { small-cell and non-small-cell lung cancers (NSCLCs), and } \\
\text { treatment of AIDS }\end{array}$ & {$[3,8,14,33]$} \\
\hline Meroterpene & Cannabinoids & $\begin{array}{l}\text { Treatment of pain relieving conditions (in cancer } \\
\text { chemotherapy, AIDS, and multiple sclerosis) }\end{array}$ & {$[8,34]$} \\
\hline \multirow[t]{2}{*}{ Triterpene } & Ginsenosides & $\begin{array}{l}\text { Anti-oxidation, anti-inflammatory, hepatoprotection, } \\
\text { anti-diabetic (hypoglycemic activity) and anti-tumor }\end{array}$ & {$[3,35,36]$} \\
\hline & Betulinic acid and its derivatives & $\begin{array}{l}\text { Anticancer, anti-inflammatory, anti-diabetic, antimicrobial } \\
\text { and anti-human immunodeficiency virus (HIV) }\end{array}$ & {$[37,38]$} \\
\hline
\end{tabular}




\subsection{Artemisinin and Its Derivatives}

The sesquiterpene endoperoxide artemisinin, which is isolated from wormwood (Artemisia annua), is the most effective traditional antimalarial drug with the property of high efficiency and low toxicity. It shows to be effective against a broader range of life cycle stages of the apicomplexan parasite than conventional antimalarials such as quinine. Antimalarial property of artemisinin arises from its extraordinary endoperoxide ring, which has an impact on overcoming Plasmodium spp. infections (Figure 2) $[3,8,39,40]$. The mechanism of action is still unclear, but there are some possible explanations. Right after the infection by Plasmodium spp., phagocytosis of red blood cells occurs and heme proteins in high levels are delivered. High concentration of heme stimulates the artemisinin, which later binds to the parasite proteins in the Plasmodium spp. body to inactivate them and consequently eradicate the infection of Plasmodium spp. [39,41].<smiles>C[C@H]1CC[C@H]2[C@@H](C)C(=O)O[C@@H]3O[C@]4(C)CC[C@@H]1[C@]32OO4</smiles>

Figure 2. Chemical structure of artemisinin.

Besides antimalarial activity, artemisinin and its derivatives have anticancer activity in vivo and in vitro, with small adverse effects. For instance, it has been reported that artesunate, which is a semisynthetic derivative of artemisinin, displays antitumor activity against several cancers, such as breast, lung, prostate, colon, ovarian, melanoma, and leukemia cancers [42]. Moreover, antibacterial and antiviral activities of these compounds were also reported in several works. Artemisinin and its derivatives have concentration dependent antibacterial activities against anaerobic, aerobic, facultative anaerobic and microaerophilic bacteria $[43,44]$. They also exhibited significant antiviral activity against the hepatitis B (HBV) and hepatitis C viruses [45]. Finally, artemisinin has been reported to have hypoglycemic effect and to be able to improve type 1 diabetes [8].

\subsection{Paclitaxel (Taxol)}

Paclitaxel, also known as its commercial brand name "Taxol", is a tricyclic diterpenoid compound (Figure 3) used as chemotherapy drug. It was first isolated from bark and needle of the pacific yew tree (Taxus brevifolia) and has effective anticancer activities on several type of tumors, such as ovarian and breast cancers. Its unique mechanism of action as a microtubule stabilizer and inhibitor of mitosis on ovarian and breast cancers was approved by the US Food and Drug Administration (FDA) in 1992 and 1994, respectively. Since then, Paclitaxel has been also widely used in the treatment of colorectal, head and neck, small-cell and non-small-cell lung cancers (NSCLCs), and acquired immune deficiency syndrome (AIDS). It contributes the conjunction of tubulin into microtubules and hinders the breakage of microtubules, which inhibits cell cycle progression, stops mitosis, and prevents the generation of tumor cells $[3,8,14,33]$.

Paclitaxel is very expensive due to its small concentration found in original plant source (yew tree). For instance, $10,000 \mathrm{~kg}$ bark of yew trees are required to produce $1 \mathrm{~kg}$ paclitaxel. This amount can treat 500 patients but requires the harvest of 300 yew trees $[14,46]$. Production is dependent on slow growth and threat of species and there is the risk of yew trees extinction. Due to these reasons, alternative sources are necessary to be developed. Until now, several other options, such as microbial production, semisynthesis and artificial cultivation of Taxus brevifolia were applied to meet world demand 
of Paclitaxel [8,14]. Moreover, the production and extraction of this compound from genetically engineered endophytic fungi has been recently announced to be an effective way as well [46].

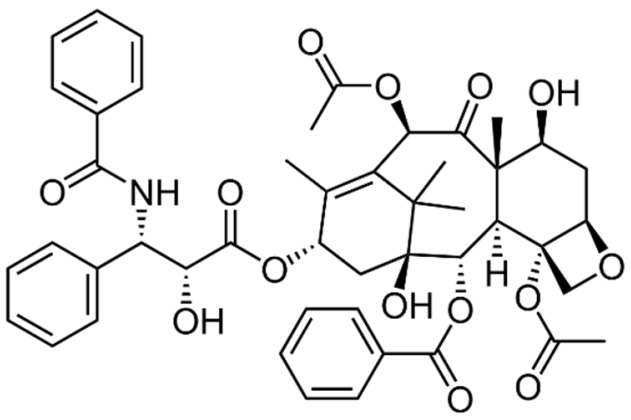

Figure 3. Chemical structure of Paclitaxel.

\subsection{Cannabinoids}

Cannabinoids comprise a group of more than 100 prenylated phenolic compounds found in Cannabis spp. (Cannabaceae), mainly in the plant Cannabis sativa. Apart from plant derivatives, Cannabinoids also involve Endocannabinoids, Phytocannabinoids, and Synthetic cannabinoids, which are able to bind to the human cannabinoid receptors $[8,34,47]$. Cannabinoid rich plants like $C$. sativa and $C$. indica have been used for different purposes for more than 5000 years. The fiber-type of Cannabis (hemp), which contains the major cannabinoid, cannabidiol (CBD) (Figure 4), has been often used in the treatment of pain relieving conditions. On the other side, $\Delta 9$-tetrahydrocannabinol (THC) (Figure 4), found in high quantity in Cannabis (marijuana), has been known for psychoactive properties, and generally used as a recreational drug and in the treatment of several medical conditions $[8,48,49]$. In addition, many pharmaceutical companies have produced several synthetic cannabinoid drugs, known by different brand names, such as Cesamet (Valeant Pharmaceuticals North America, Bridgewater, NJ, USA), Marinol (Unimed Pharmaceuticals Inc., Marietta, GA, USA), and Sativex (GW Pharmaceuticals plc, Cambridge, UK). These drugs have been used in Canada, USA, UK, and other countries to treat nausea and vomiting caused by cancer chemotherapy, anorexia associated with weight loss in patients with AIDS, and symptomatic relief of neuropathic pain in multiple sclerosis $[34,50]$.

A<smiles>CCCCCc1cc(O)c2c(c1)OC(C)(C)[C@@H]1CCC(C)=C[C@H]21</smiles>

B

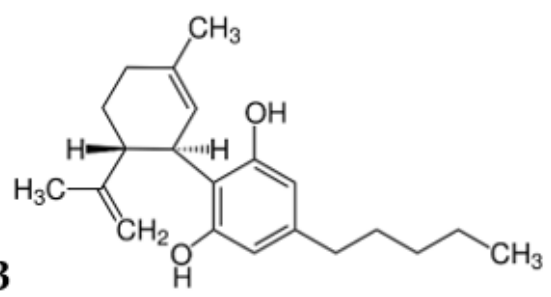

Figure 4. Chemical structure of $\triangle 9$-tetrahydrocannabinol (THC) (A) and cannabidiol (CBD) (B).

Cannabinoids also called as terpenophenolic in the class of meroterpene, are produced as secondary metabolite of Cannabis through concatenation of isoprenoid precursor with a second fatty acid derivative precursor by a prenyltransferase enzyme. This enzyme synthesizes cannabigerolic acid (CBGA), through the prenylation of olivetolic acid and geranyl diphosphate (GPP). CBGA is then converted into different cyclized compounds, such as tetrahydrocannabinolic acid (THCA), cannabidiolic acid (CBDA), and cannabichromenic acid (CBCA). Finally, these compounds undergo decarboxylation to produce biologically active compounds THC, CBD, and CBC, which are the main cannabinoids placed in Cannabis spp. $[2,8,34,51]$.

In recent years, Cannabis spp. has been legally used for the medical treatments in many countries, such as USA, Canada, Israel, and several European countries including 
the Netherlands, Germany, and the Czech Republic. However, Cannabis spp. cannot be cultivated in several countries due to the legal issues. Agricultural production of cannabinoids via Cannabis cultivation has several disadvantages, such as low yield due to climate changes and plant diseases, low concentrations of cannabinoids in plant, necessity of extraction processes, and sociopolitical factors for the use of Cannabis, which has been mostly seen as a source of narcotics. On the other hand, chemical synthesis of cannabinoids does not offer an alternative production way because of synthesis complexity, which generally causes low yields and high production cost. For these reasons, microbial production of these compounds by engineered yeast would serve a sustainable, reliable, eco-friendly, and cost-effective alternative approach $[2,34]$.

\subsection{Other Medically Important Terpenoids}

Apart from artemisinin, taxol, and cannabinoids, there are also other medically important terpenoids with several pharmaceutical activities and functions. It was reported that the monoterpenes perillyl alcohol, D-limonene, and geraniol are effective in the prevention and treatment of various types of cancers (Figure 5) [3,52,53]. They have therapeutic or prophylactic effects on breast, lung, colon, prostate, pancreatic, and liver cancers [3]. Their main mechanism to prevent cancer activity consists in the inhibition of posttranslational isoprenylation of proteins, which are responsible for the growth of tumor cells [52]. Besides antitumor activity, some monoterpenes (e.g., menthol, limonene, and sabinene) have antimicrobial effects on diverse type of microorganisms, such as Bacillus subtilis, Staphylococcus aureus, Streptococcus spp., E. coli, and Candida albicans [3,54]. In addition, menthol and limonene promote the transdermal absorption of drugs through the human skin $[3,54]$. These terpenoids show little skin irritation, low toxicity, and high activity. The sesquiterpene patchouli alcohol also presented antibacterial activity on Helicobacter pylori [32]. In addition, triterpene ginsenosides have various pharmacological effects, such as anti-oxidation, anti-inflammatory, hepatoprotection, anti-diabetic (hypoglycemic activity), and antitumor [36]. They also exhibit therapeutic effects on the prevention and treatment of various cardiovascular diseases, such as regulation of vascular function, inhibition of cardiomyocyte hypertrophy and thrombosis [3]. In addition, betulinic acid (Figure 5) and its semisynthetic derivatives, such as PA-457, have also shown remarkable pharmacological properties, including inhibitory effects against human immunodeficiency virus (HIV) and cytotoxicity activity on several type of cancer cells (Table 1) [37,38]. Very interestingly, biotransformation of betulinic acid has been continuously investigated aiming at discovering novel derivatives for pharmacological studies [55]. 
<smiles>C=C(C)[C@H]1CC=C(C)CC1</smiles><smiles>C=C1CC[C@]2(C(C)C)C[C@H]1C2</smiles><smiles>CC[C@@H]1[C@@H](C)CC[C@H](O)[C@@H]1C</smiles>

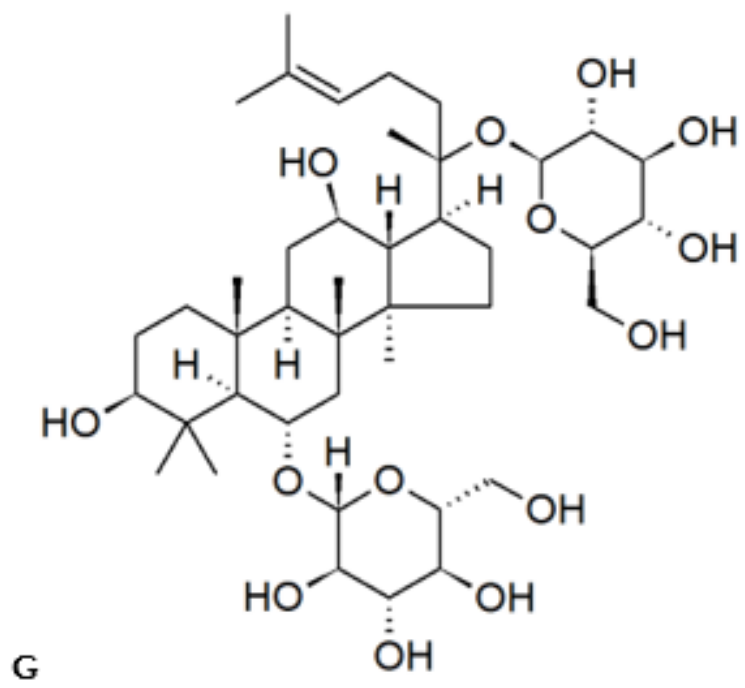

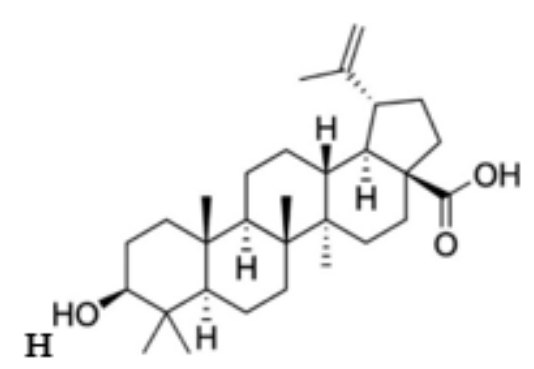

Figure 5. Chemical structure of (A) Perillyl alcohol, (B) D-limonene, (C) Geraniol, (D) Menthol, (E) Sabinene, (F) Patchouli alcohol, (G) Ginsenoside and (H) Betulinic acid.

\section{Biosynthesis of Medically Important Terpenoids}

Terpenoid biosynthesis can be divided into four main stages. In the first stage, universal building blocks isopentenyl diphosphate (IPP) and dimethylallyl diphosphate (DMAPP) are synthesized via the mevalonate pathway (MVA pathway) and the methyl-erythritol phosphate pathway (MEP pathway). MVA pathway, which exists in S. cerevisiae, starts from acetyl-CoA and ends up with the production of DMAPP. In the second stage, geranyl pyrophosphate (GPP), farnesyl pyrophosphate (FPP), or geranylgeranyl pyrophosphate (GGPP), which are the precursors of monoterpenoids, sesquiterpenoids, or diterpenoids, respectively, are created by condensation reactions of one molecule DMAPP with one, two, or three molecules of IPP under the action of isopentenyl transferase. On the other hand, triterpenoids are similarly generated via polymerization of two molecules of FPP. In the third stage, these linear isopentenyl pyrophosphate precursors are cyclized or rearranged by terpene synthases to form primary terpene carbon skeleton. Finally, this carbon skeleton undergoes several post-modifications and tailoring reactions (oxidations, acetylation, ester- 
ification, alkylation, etc.) under the action of cytochrome P450s (CYPs) to form biologically active terpenoids (for recent reviews see: $[5,12,56]$ ).

\section{Metabolic Engineering Strategies for Pharmaceutic Terpenoids Production in Yeast}

A brief overview of metabolic engineering applications in S. cerevisiae for terpenoid biosynthesis is herein given. The common metabolic engineering strategies for terpenoids synthesis in yeast, as described in recent reviews $[5,7,56-58]$ can be summarized as such:

1. Modifying endogenous pathways for synthesis of desired terpenoids.

2. Finding and introducing new heterologous enzymes and pathways into yeast.

3. Determination of rate limiting steps in selected pathways by application of omics studies.

4. Elimination of rate limiting steps in target pathways via overexpression of genes, and cofactor and transporter engineering.

5. Developing enzyme activity and/or specificity by protein engineering.

6. Improving expression level of target key enzymes.

7. Blocking or down regulating competing pathways.

8. Increasing precursor and cofactor supply.

9. Balancing cell growth and terpenoid synthesis for fermentation process.

As above mentioned, the direct precursors in sterol pathway, FPP, GPP, GGPP, and squalene epoxide, can be converted into specific terpenes through a series of enzymes designated as terpene synthases, which do not exist in S. cerevisiae. For this reason, heterologous genes for the functional expression of terpene synthases from plant resources (e.g., taxadiene synthases from Taxus brevifolia) or synthetic sources (from NCBI gene accession number) should be introduced into S. cerevisiae [57]. On the other hand, Cytochrome P450 (CYPs), which are essential enzymes to modify the hydrocarbon products from terpene synthases, catalyze a wide variety of metabolic reactions, such as oxygenations, deamination, decarboxylation, dealkylation, and C-C cleavage [59]. S. cerevisiae has only three CYPs, which are Erg5 and Erg11 in the ergosterol pathway and Dit2 (putative cytochrome P450 involved in the synthesis of $\mathrm{N}, \mathrm{N}$-bisformyl dityrosine). For specific or non-native terpenoid production, heterologous expression of CYPs is required. As a successful example, ref. [27] have expressed CYP71AV1, NADPH dependent cytochrome P450 oxidoreductases (CPR1) and cytochrome b5 (CYB5) from A. annua in S. cerevisiae, obtaining $25 \mathrm{~g} / \mathrm{L}$ of artemisinic acid in optimized fed-batch fermentation.

Another strategy is to identify the rate limiting reactions and overexpress the gene, or genes, responsible for these reactions to promote flux into the MVA pathway of $S$. cerevisiae. HMG-CoA reduction to MVA, catalyzed by Hmg1p or Hmg2p, products of HMG1 and HMG2, respectively, was reported as the rate limiting step in the sterol pathway of S. cerevisiae. Overexpression of N-terminal truncated HMG1 (tHMG1) and Hmg2p in anaerobic conditions increased squalene titer in this yeast [7,57]. Moreover, overexpression of the transcriptional factor Upc2-1, constitutively active mutant of Upc2, improved sterols uptake [7]. As a similar strategy, overexpression of all structural genes in MVA pathway (ERG10, ERG13, tHMG1, ERG12, ERG8, IDI1, and ERG20) has enhanced terpenoid production $[26,60]$. In addition, down-regulation of downstream genes of competitive pathways can increase the precursor pool. For instance, down regulation of ERG9 in low glucose concentrations through HTX1 promoter, could increase FPP pool in fed-batch fermentations [61].

Acetyl-CoA and NADPH are the essential precursor and cofactor for the biosynthesis of several products (sterols, fatty acids, and polyketides) as well as terpenoids. Overexpression of structural genes in MVA pathway in S. cerevisiae to improve terpenoid synthesis results in draining the acetyl-CoA and NADPH pools, which may negatively affect the cell growth, causing in parallel the decrease in the terpenoid production. Therefore, the increase of cytosolic acetyl-CoA and NADPH pools is required. The most effective way for achieving this was to establish a synthetic pathway. Ref. [26] combined acetaldehyde dehydrogenase (which converts acetaldehyde to acetyl-CoA) with xylulose-5-phosphate- 
specific phosphoketolase and phosphotransacetylase (which convert xylulose-5-phosphate to acetyl-CoA) to increase acetyl-CoA pool. Moreover, the same authors have used an NADH-consuming HMG-CoA reductase to increase NADPH pool. This new pathway lead to improved $\beta$-farnesene production along with $75 \%$ less oxygen requirement in fed-batch fermentation [26].

Interestingly, to expand the diversity of terpenoid structures, C11 terpene scaffolds were produced in S. cerevisiae by engineering dedicated synthases upon identification of a single residue switch that converts $\mathrm{C} 10$ plant monoterpene synthases to $\mathrm{C} 11$ specific enzymes [62]. More recently, a synthetic orthogonal monoterpenoid pathway based on an alternative precursor, neryl diphosphate, was established in yeast, in which five engineered enzymes were combined with dynamic regulation of metabolic flux to take advantage of the orthogonal substrate potential and improve monoterpenes production [63].

\section{Factors Affecting Fermentation Process of Pharmaceutical Terpenoids}

The main factors affecting the production of terpenoids in S. cerevisiae include strain engineering, inoculum size, $\mathrm{pH}$ value, temperature, oxygen rate, and fermentation medium composition such as carbon and nitrogen sources. In addition, secondary products like ethanol, and some organic acids can affect the productivity of terpenoids. Below, the general factors affecting terpenoid biosynthesis are discussed.

\subsection{Strain Engineering}

Wild type $S$. cerevisiae strains (most known laboratory strains used for system biology: CENPK, S288C, BY4741 and W303, www.yeastgenome.org, accessed on 26 March 2021) have endogenous sterol biosynthesis process, including MVA pathway. Ergosterol is synthesized through this process. By using molecular biology methods, namely gene deletion and high-through screening methods, all enzymes and genes upstream the MVA pathway, and downstream ergosterol synthesis in S. cerevisiae, have been clarified [64]. Terpenoids cannot be directly produced by wild type strains of $S$. cerevisiae without genetic modifications because it requires the availability of precursors for transfer of intermediates between compartments (the cytoplasm and endoplasmic reticulum) and diverse class of Cytochrome P450 (CYP-CPR) enzymes for the oxygenation reactions to produce structurally diverse terpenes [57]. In order to produce terpenoids efficiently in yeast, several genetic modifications such as promoter alterations, gene mutations, genes knockout and expression of heterologous genes were required (see recent reviews: $[2,6,12,65]$. Highly engineered strains of S. cerevisiae, with the capability to produce different type of terpenoids, including industrial products, such as farnesene, artemisinin, patchouli alcohol, squalene, geraniol, and $\beta$-carotene, have been constructed [5]. However, different gene regulation is necessary for different type of end-products. For instance, in sesquiterpenes production, ERG9 enzyme is required to be downregulated to lower the metabolic flow from farnesyl pyrophosphate to squalene, while in triterpenoids production, the same enzyme is upregulated to increase precursors pull for triterpenoids [64]. In addition, distinctive plant derived cytochrome P450 enzymes for specific target products should be cloned and expressed as well [12]. Because of these reasons, tailor-made engineered strains need to be constructed for specify target terpenoids $[7,56]$. Some of the important genetic modifications for different terpenoid biosynthesis are presented in Table 2.

Table 2. Relevant engineering strategies performed in Saccharomyces cerevisiae for terpenoid production (adapted from [7]).

\begin{tabular}{|c|c|c|c|}
\hline Compound & Titer & Strategy & References \\
\hline Amorpha-4,11-diene & $>40 \mathrm{~g} / \mathrm{L}$ & $\begin{array}{c}\text { Overexpression of ADS, upc2-1 } \\
\text { Integration of genes copies using control of galactose-inducible promoters: } 3 \text { copies of } \\
\text { tHMG1, and ERG10, 13, 12, 8, and IDI1 } \\
\text { Deletion of gal80 } \\
\text { Downregulation of ERG9 }\end{array}$ & [60] \\
\hline
\end{tabular}


Table 2. Cont.

\begin{tabular}{|c|c|c|c|}
\hline Compound & Titer & Strategy & References \\
\hline Artemisinic acid & $25 \mathrm{~g} / \mathrm{L}$ & $\begin{array}{c}\text { Overexpression of ADS, CYP71AV1, CPR1, CYB5, ALDH1 and ADH1 from A. } \\
\text { annua, HEM1, and CTT1 under control of } \\
\text { galactose-inducible promoters } \\
\text { Deletion of gal80 } \Delta \\
\text { Downregulation of ERG9 }\end{array}$ & [27] \\
\hline Farnesene & $130 \mathrm{~g} / \mathrm{L}$ & $\begin{array}{c}\text { Overexpression of ADA, xPK, PTA, } \\
\text { NADH-HMGr, Farnesene synthase } \\
\text { Deletion of adh1 } \Delta, \text { ald } 4 \Delta \text {, ald6 } 6 \text {, gpp1 } \Delta \text {, gal2 } 2 \Delta \text {, bdh1 } \Delta \\
\text { Overexpression of enzymes of the MVA pathway to Erg20 } \\
\text { Downregulation of ERG9 }\end{array}$ & [26] \\
\hline Bisabolone & $>900 \mathrm{mg} / \mathrm{L}$ & $\begin{array}{c}\text { Overexpression of tHMG1, ERG20, upc2-1 and bisabolene synthase } \\
\text { Downregulation of ERG9 }\end{array}$ & {$[66]$} \\
\hline Alpha-Santalene & $92 \mathrm{mg} / \mathrm{L}$ & $\begin{array}{l}\text { Overexpression of tHMG1 } \\
\text { Deletion of Ipp1 } \Delta, \text { dpp1 } \Delta \\
\text { Downregulation of ERG9 }\end{array}$ & {$[61]$} \\
\hline Patchoulol & $42.1 \mathrm{mg} / \mathrm{L}$ & $\begin{array}{l}\text { Overexpression of ERG20 and PatTps177 } \\
\text { Downregulation of ERG9 }\end{array}$ & [67] \\
\hline (S)-Linalool & $0.26 \mathrm{mg} / \mathrm{L}$ & $\begin{array}{c}\text { Overexpression of Erg20 and (S)-linalool synthase } \\
\text { Diploid }\end{array}$ & [68] \\
\hline Geraniol & $1.69 \mathrm{~g} / \mathrm{L}$ & $\begin{array}{c}2 \mu \text { plasmid of PTEF1-tVoGES-(GGGS)-ERG20WW fusion protein } \\
2 \mu \text { plasmid of PTEF1-tHMG1, PPGK1-IDI1, PTEF1- upc2.1 } \\
\text { PHXT1-ERG20, oye2 } \Delta\end{array}$ & [69] \\
\hline Sabinene & $1.75 \mathrm{mg} / \mathrm{L}$ & $\begin{array}{c}2 \mu \text { plasmid of PTDH3-ERG20 (F96W-N127W)- sabinene synthase (Salvia } \\
\text { pomifera) fusion protein } \\
\text { Diploid ERG9/erg9, ERG20/erg20, } \\
\text { PGal1-HMG2 (K6R), PTDH3-HMG2 (K6R) } \times 2\end{array}$ & {$[70]$} \\
\hline
\end{tabular}

\subsection{Carbon Source}

The selection of fermentation carbon source depends on the precursor pool designed to be used [60]. Ethanol was often fed to fermentation broth as substrate since it can be readily directed to acetyl-CoA formation [69]. It was preferred instead of glucose as carbon source during the production phase due to increased higher titer and yield in the accumulation of many terpenoids in S. cerevisiae, such as amorpha-4,11-diene (precursor of artemisinin) [60], artemisinic acid [27], $\beta$-amyrin [71], limonene [72], geraniol [73], protopanoxadiol [74], and patchoulol [22] (Table 3). In these studies, diauxic yeast fermentation process was performed, in which glucose is consumed in the first stage of cell growth with the simultaneous production of ethanol that is then used in the second stage of cell growth and biosynthesis of the product of interest [72]. However, high ethanol concentration results in cell stress in S. cerevisiae. As a response to this situation, ergosterol synthesis is usually stimulated. This metabolic mechanism had improved the availability of the main precursor 2,3-oxidosqualene, resulting in two times higher total triterpenoid productivities and 2.4fold increase in carbon yield in ethanol pulse fed fermentations, compared to glucose fed fermentations [75]. However, the use of ethanol as main carbon source is not feasible for industrial terpenoid production, due to its high cost as compared to other carbon sources like glucose. To date, glucose, which is the most widely used carbon source in bioprocesses, has been also selected as feedstock to reach high titer and yield during fermentation of several terpenoids, such as bisabolone [76], zerumbone [77], $\alpha$-humulene [4], $\alpha$-santalene [61], miltiradiene [78], protopanaxadiol and dammarenediol-II [79], and ginsenoside Rh2 [35] (Table 3). In addition, the promoters chosen to drive expression of heterologous genes also affect the choice of the substrate. For instance, when gal-promoters were used in the construction of engineered yeast, galactose was required to be included in the medium 
in order to induce the expression of cloned genes, while being used as carbon source at the same time [57]. Some terpenoids were produced using galactose as sole carbon source, such as limonene [80], (-)-limonene [81], sabinene [70], bisabolene [66], valerenic acid [82], and polpulonic acid [20] (Table 3). However, using galactose as sole carbon source makes the process expensive and regulation by galactose can be only repressed in the presence of glucose. Because of this, the Gal1 gene was deleted to produce artemisinic acid from glucose as a primary carbon source instead of galactose, where galactose was supplemented in low amount as a gratuitous inducer [60]. Apart from these carbon sources, molasses, which consists mainly of sucrose, disaccharide composed of glucose, and fructose, is commonly used as carbon source in many industrial fermentations [17,83]. Ref. [84] produced nerolidol from sucrose as sole carbon source in carbon-overflow fed-batch fermentation by employing the diauxic-induction system, including the four characterized GAL promoters. Moreover, besides these carbon sources, raffinose and dextrose were also used in a mixture with galactose or glucose in the production of polpulonic acid [20] and $\beta$-amyrin [85], respectively. However, from all employed carbon sources, the highest specific production rates were achieved when using ethanol in the diauxic yeast fermentation process $[27,60,69]$. Rather than these hexoses, disaccharide sucrose, as well as ethanol, agricultural byproducts like sugar cane bagasse or straw, which comprise mostly of xylose and glucose, as well as other sugars like galactose, can be considered as alternative feedstock for terpenoid bioprocess [7]. In addition, as a byproduct of biodiesel production, crude glycerol also has potential to be used as economic alternative source [86]. However, S. cerevisiae strains are unable to metabolize xylose and, thus, metabolic engineering must be performed, by introducing appropriate heterologous genes of xylose pathway in this yeast, to allow fermentation of this pentose. Significant advances have been made in recent years in regard of xylose use by yeast to obtain value-added bioproducts [87]. Overall, non-fermentable carbon sources (e.g., ethanol and glycerol) are more effective for attaining high terpenoid yields than fermentable ones (e.g., glucose, fructose, sucrose, and galactose) [86]. This is because the metabolic pathways of the non-fermentable carbon sources are highly flexible and involve the glyoxylate cycle and an increased number of mitochondrial shuttles in yeast [86]. 
Table 3. Terpene titers obtained in S. cerevisiae and respective fermentation strategies.

\begin{tabular}{|c|c|c|c|c|c|c|c|c|c|c|c|c|}
\hline Group & Product & $\begin{array}{c}\text { Titer } \\
(\mathrm{mg} / \mathrm{L})\end{array}$ & Carbon Source & $\begin{array}{l}\text { Nitrogen } \\
\text { Source }\end{array}$ & $\mathrm{pH}$ & ${ }^{\circ} \mathrm{C}$ & $\begin{array}{c}\text { Aeration } \\
\text { /Agitation }\end{array}$ & $\begin{array}{c}\text { Dissolved } \\
\text { Oxygen }\end{array}$ & $\begin{array}{l}\text { Inoculum } \\
\text { Size }\end{array}$ & $\begin{array}{l}\text { Feeding } \\
\text { Strategy }\end{array}$ & $\begin{array}{l}\text { Operation } \\
\text { Mode }\end{array}$ & References \\
\hline \multirow{9}{*}{ 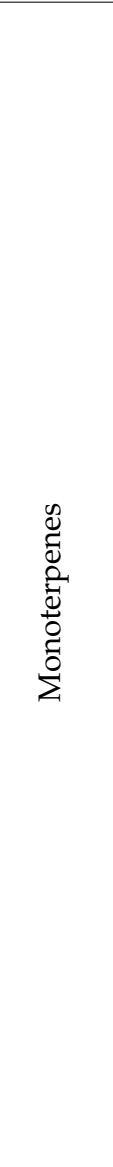 } & Limonene & 1.48 & $\begin{array}{l}2 \mathrm{~g} / \mathrm{L} \text { glucose and } \\
18 \mathrm{~g} / \mathrm{L} \text { galactose }\end{array}$ & $\left(\mathrm{NH}_{4}\right)_{2} \mathrm{SO}_{4}$ & - & 30 & $200 \mathrm{rpm}$ & - & ${ }^{1} \mathrm{OD}=0.05$ & - & Shake-flask & [80] \\
\hline & $\begin{array}{c}(-)- \\
\text { Limonene }\end{array}$ & 0.49 & $\begin{array}{l}20 \mathrm{~g} / \mathrm{L} \text { glucose and } \\
20 \mathrm{~g} / \mathrm{L} \text { galactose }\end{array}$ & $\left(\mathrm{NH}_{4}\right)_{2} \mathrm{SO}_{4}$ & - & 30 & $300 \mathrm{rpm}$ & - & $\mathrm{OD}=0.05$ & - & Shake-flask & [81] \\
\hline & Limonene & 918 & $\begin{array}{c}20 \mathrm{~g} / \mathrm{L} \text { initial } \\
\text { glucose and } 10 \mathrm{~g} / \mathrm{L} \\
\text { pure ethanol }\end{array}$ & $\begin{array}{l}\text { Tryptone, } \\
\text { Yeast } \\
\text { extract }\end{array}$ & - & 30 & $250 \mathrm{rpm}$ & - & $\mathrm{OD}=0.2$ & Pure ethanol & $\begin{array}{l}\text { Fed-Batch in } \\
\text { shake flask }\end{array}$ & [72] \\
\hline & Geraniol & 5 & $10 \mathrm{~g} / \mathrm{L}$ glucose & $\left(\mathrm{NH}_{4}\right)_{2} \mathrm{SO}_{4}$ & - & 28 & - & - & $2.5 \%$ & - & Shake-flask & [88] \\
\hline & Geraniol & 293 & $\begin{array}{c}20 \mathrm{~g} / \mathrm{L} \text { initial } \\
\text { glucose and then } \\
\text { fed solution } \\
\text { (glucose and other } \\
\text { nutrients) }\end{array}$ & $\left(\mathrm{NH}_{4}\right)_{2} \mathrm{SO}_{4}$ & 6.0 & 30 & $\begin{array}{l}600 \mathrm{rpm} / \\
1 \mathrm{vvm}\end{array}$ & $>30 \%$ & $\mathrm{OD}=0.15$ & $\begin{array}{l}\text { Fed solution (glucose } \\
\text { and other nutrients) } \\
\text { feeding by } \\
\text { controlling the } \\
\text { specific feed rate to } \\
0.1 \mathrm{~h}^{-1}\end{array}$ & Fed-Batch & [69] \\
\hline & Geraniol & 1680 & $\begin{array}{l}\text { Initial YPD } \\
\text { medium, then } \\
\text { glucose and } \\
\text { ethanol }\end{array}$ & $\begin{array}{c}\text { Yeast } \\
\text { extract, } \\
\text { Peptone }\end{array}$ & 5.7 & 30 & $\begin{array}{c}300- \\
500 \mathrm{rpm} / \\
2 \mathrm{vvm}\end{array}$ & $>30 \%$ & $10 \%$ & $\begin{array}{l}\text { Glucose feeding } \\
\text { under } 1 \mathrm{~g} / \mathrm{L} \text { and } \\
\text { ethanol feeding } \\
\text { under } 5 \mathrm{~g} / \mathrm{L}\end{array}$ & $\begin{array}{l}\text { Fed-Batch } \\
\text { (Carbon } \\
\text { restricted) }\end{array}$ & [73] \\
\hline & Geraniol & 1690 & $\begin{array}{l}\text { Initial } 20 \mathrm{~g} / \mathrm{L} \\
\text { glucose then pure } \\
\text { ethanol feeding }\end{array}$ & $\left(\mathrm{NH}_{4}\right)_{2} \mathrm{SO}_{4}$ & 5.0 & 30 & $\begin{array}{l}600 \mathrm{rpm} / \\
1 \mathrm{vvm}\end{array}$ & $>30 \%$ & $\mathrm{OD}=0.2$ & $\begin{array}{l}400 \mathrm{~g} / \mathrm{L} \text { pure ethanol } \\
\text { at } 0.1 \mathrm{~L} / \mathrm{h} \text { feed rate }\end{array}$ & Fed-Batch & [69] \\
\hline & Sabinene & 17.5 & $\begin{array}{c}20 \mathrm{~g} / \mathrm{L} \text { glucose } \\
20 \mathrm{~g} / \mathrm{L} \text { galactose } \\
\text { and } \\
10 \mathrm{~g} / \mathrm{L} \text { raffinose }\end{array}$ & $\left(\mathrm{NH}_{4}\right)_{2} \mathrm{SO}_{4}$ & - & - & - & - & - & - & - & [70] \\
\hline & (S)-linalool & 0.26 & $20 \mathrm{~g} / \mathrm{L}$ glucose & $\begin{array}{l}\text { Yeast } \\
\text { extract }\end{array}$ & 5.5 & 30 & $\begin{array}{c}400 \mathrm{rpm} / \\
2 \mathrm{vvm}\end{array}$ & - & $\mathrm{OD}=0.05$ & - & $\begin{array}{c}\text { Batch } \\
\text { Bioreactor }\end{array}$ & [68] \\
\hline
\end{tabular}


Table 3. Cont.

\begin{tabular}{|c|c|c|c|c|c|c|c|c|c|c|c|c|}
\hline Group & Product & $\begin{array}{l}\text { Titer } \\
(\mathrm{mg} / \mathrm{L})\end{array}$ & Carbon Source & $\begin{array}{l}\text { Nitrogen } \\
\text { Source }\end{array}$ & $\mathrm{pH}$ & ${ }^{\circ} \mathrm{C}$ & $\begin{array}{l}\text { Aeration } \\
\text { /Agitation }\end{array}$ & $\begin{array}{l}\text { Dissolved } \\
\text { Oxygen }\end{array}$ & $\begin{array}{l}\text { Inoculum } \\
\text { Size }\end{array}$ & $\begin{array}{l}\text { Feeding } \\
\text { Strategy }\end{array}$ & $\begin{array}{l}\text { Operation } \\
\text { Mode }\end{array}$ & References \\
\hline \multirow{6}{*}{ 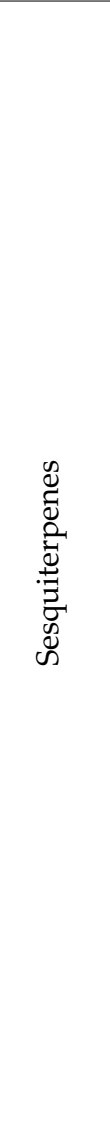 } & Bisabolone & 900 & $\begin{array}{l}2 \mathrm{~g} / \mathrm{L} \text { glucose and } \\
18 \mathrm{~g} / \mathrm{L} \text { galactose }\end{array}$ & $\begin{array}{c}\text { Yeast } \\
\text { extract, } \\
\text { peptone }\end{array}$ & - & 30 & $180 \mathrm{rpm}$ & - & $\mathrm{OD}=0.05$ & - & Shake-flask & {$[66]$} \\
\hline & Bisabolone & 5200 & $\begin{array}{l}\text { Initial } 15 \mathrm{~g} / \mathrm{L} \\
\text { glucose }\end{array}$ & $\left(\mathrm{NH}_{4}\right)_{2} \mathrm{SO}_{4}$ & 5.0 & 30 & $\begin{array}{l}0.7 \mathrm{~L} / \mathrm{min} \\
\text { air }\end{array}$ & - & $\mathrm{OD}=0.1$ & $\begin{array}{l}\text { Constant feed rate } \\
\text { with } p H \text { rise trigger }\end{array}$ & Fed-batch & [76] \\
\hline & Nerolidol & 336.5 & $20 \mathrm{~g} / \mathrm{L}$ sucrose & $\left(\mathrm{NH}_{4}\right)_{2} \mathrm{SO}_{4}$ & - & 30 & $180 \mathrm{rpm}$ & - & $\mathrm{OD}=0.2$ & - & $\begin{array}{l}\text { Two-phase } \\
\text { flask } \\
\text { cultivation }\end{array}$ & [19] \\
\hline & Nerolidol & 5500 & $\begin{array}{l}\text { Initial } 20 \mathrm{~g} / \mathrm{L} \\
\text { glucose, and then } \\
\text { sucrose feeding }\end{array}$ & $\left(\mathrm{NH}_{4}\right)_{2} \mathrm{SO}_{4}$ & 5.0 & - & $\begin{array}{c}300- \\
600 \mathrm{rpm} / 1.58- \\
3.16 \mathrm{~L} / \mathrm{h} \\
\text { air }\end{array}$ & $30 \%$ & $\mathrm{OD}=0.2$ & $\begin{array}{l}\text { Exponential feeding } \\
(3 \mathrm{mM} \text { sucrose } / \mathrm{g} \\
\text { biomass } / \mathrm{h}) \text { with } \\
\text { specific increasing } \\
\text { rate }\left(0.05 \mathrm{~h}^{-1} \text { then }\right. \\
20 \mathrm{~g} / \mathrm{L} \text { sucrose pulse } \\
\text { feeding by DO spikes }\end{array}$ & Fed-Batch & [84] \\
\hline & $\begin{array}{l}\text { Polpunonic } \\
\text { acid }\end{array}$ & 1.4 & $\begin{array}{c}20 \mathrm{~g} / \mathrm{L} \text { galactose } \\
\text { and } 10 \mathrm{~g} / \mathrm{L} \\
\text { raffinose }\end{array}$ & - & - & 30 & $150 \mathrm{rpm}$ & - & - & - & Shake-flask & [20] \\
\hline & $\begin{array}{l}\text { Amorpha- } \\
\text { 4,11-diene }\end{array}$ & $>4000$ & $\begin{array}{l}\text { Initial } 20 \mathrm{~g} / \mathrm{L} \\
\text { glucose then pure } \\
\text { ethanol pulse } \\
\text { feeding, } 0.25 \mathrm{~g} / \mathrm{L} \\
\text { methionine as } \\
\text { inducer }\end{array}$ & $\left(\mathrm{NH}_{4}\right)_{2} \mathrm{SO}_{4}$ & 5.0 & 30 & $1 \mathrm{~L} /$ min air & $40 \%$ & - & $\begin{array}{c}\text { Ethanol pulse feed } \\
(10 \mathrm{~g} / \mathrm{L}), \text { Off-gas } \\
\mathrm{CO}_{2} \text { evaluation rate } \\
\text { control }\end{array}$ & Fed-Batch & [60] \\
\hline
\end{tabular}


Table 3. Cont

\begin{tabular}{|c|c|c|c|c|c|c|c|c|c|c|c|c|}
\hline Group & Product & $\begin{array}{c}\text { Titer } \\
(\mathrm{mg} / \mathrm{L})\end{array}$ & Carbon Source & $\begin{array}{l}\text { Nitrogen } \\
\text { Source }\end{array}$ & $\mathrm{pH}$ & ${ }^{\circ} \mathrm{C}$ & $\begin{array}{l}\text { Aeration } \\
\text { /Agitation }\end{array}$ & $\begin{array}{c}\text { Dissolved } \\
\text { Oxygen }\end{array}$ & $\begin{array}{l}\text { Inoculum } \\
\text { Size }\end{array}$ & $\begin{array}{l}\text { Feeding } \\
\text { Strategy }\end{array}$ & $\begin{array}{l}\text { Operation } \\
\text { Mode }\end{array}$ & References \\
\hline & $\begin{array}{l}\text { Artemisinic } \\
\text { acid }\end{array}$ & 25,000 & $\begin{array}{c}\text { Initial } 20 \mathrm{~g} / \mathrm{L} \\
\text { glucose then pure } \\
\text { ethanol pulse } \\
\text { feeding, } 0.25 \mathrm{~g} / \mathrm{L} \\
\text { methionine as } \\
\text { inducer }\end{array}$ & $\left(\mathrm{NH}_{4}\right)_{2} \mathrm{SO}_{4}$ & 5.0 & 30 & $1 \mathrm{~L} / \mathrm{min}$ air & $40 \%$ & - & $\begin{array}{l}\text { Etanol pulse }(10 \mathrm{~g} / \mathrm{L}) \\
\text { feed, stir rate control }\end{array}$ & Fed-Batch & [27] \\
\hline & Patchoulol & 467 & $\begin{array}{l}\text { Initial glucose } \\
(25 \mathrm{~g} / \mathrm{L}) \text { feeding, } \\
\text { Feeds: (1) Sole } \\
\text { glucose feeding (2) } \\
\text { glucose/glycerol } \\
\text { feeding, (3) Sole } \\
\text { ethanol feeding }\end{array}$ & $\begin{array}{c}\left(\mathrm{NH}_{4}\right)_{2} \mathrm{SO}_{4} \\
\text { Peptone. } \\
\text { Yeast } \\
\text { extract }\end{array}$ & 5.5 & 30 & $\begin{array}{c}200- \\
500 \mathrm{rpm} / \\
1-2 \mathrm{vvm}\end{array}$ & - & $14 \%$ & $\begin{array}{c}\text { carbon-source } \\
\text { (glucose) controlled } \\
\text { three-stage } \\
\text { fermentation }\end{array}$ & Fed-Batch & [22] \\
\hline & Zerumbone & 40 & $\begin{array}{c}\text { Initial } 20 \mathrm{~g} / \mathrm{L} \\
\text { glucose, then feed } \\
\text { solution (glucose, } \\
\text { other nutrients and } \\
\text { ingredients) }\end{array}$ & $\begin{array}{l}\text { Peptone. } \\
\text { Yeast } \\
\text { extract }\end{array}$ & 5.5 & 30 & $\begin{array}{c}300- \\
600 \mathrm{rpm} / \\
2 \mathrm{vvm}\end{array}$ & $>30 \%$ & $5 \%$ & $\begin{array}{l}\text { Fed rate solution } \\
\text { (glucose and other } \\
\text { nutrients, } \\
\text { ingredients) of } 2 \\
\mathrm{~mL} / \mathrm{min} \text { control by } \\
\mathrm{DO} \text { and } \mathrm{pH} \text { rise } \\
\text { trigger }\end{array}$ & Fed-Batch & [77] \\
\hline & $\begin{array}{c}\alpha- \\
\text { humulene }\end{array}$ & 1700 & $\begin{array}{c}\text { Initial } 20 \mathrm{~g} / \mathrm{L} \\
\text { glucose, then feed } \\
\text { solution (glucose, } \\
\text { other nutrients and } \\
\text { ingredients) }\end{array}$ & $\begin{array}{l}\text { Peptone. } \\
\text { Yeast } \\
\text { extract }\end{array}$ & 5.5 & 30 & $\begin{array}{c}300- \\
600 \mathrm{rpm} / \\
2 \mathrm{vvm}\end{array}$ & $>30 \%$ & $10 \%$ & $\begin{array}{l}\text { Fed rate solution } \\
\text { (glucose and other } \\
\text { nutrients, } \\
\text { ingredients) of } 2 \\
\mathrm{~mL} / \mathrm{min} \text { control by } \\
\mathrm{DO} \text { and } \mathrm{pH} \text { rise } \\
\text { trigger }\end{array}$ & Fed-Batch & {$[4]$} \\
\hline & $\alpha$-santalene & $\begin{array}{c}0.036 \\
\text { Cmmol (g/ } \\
\text { biomass } / \mathrm{h})\end{array}$ & $\begin{array}{l}\text { Initial } 10 \mathrm{~g} / \mathrm{L} \\
\text { glucose and } \\
\text { continuous glucose } \\
\text { and dodecane } \\
\text { feeding }\end{array}$ & $\left(\mathrm{NH}_{4}\right)_{2} \mathrm{SO}_{4}$ & 5.0 & 30 & $\begin{array}{l}600 \mathrm{rpm} / \\
1 \mathrm{vvm}\end{array}$ & $>30 \%$ & ${ }^{2} \mathrm{Xi}=1 \mathrm{~g} / \mathrm{L}$ & $\begin{array}{c}\text { Two phase feeding } \\
\text { (organic phase and } \\
10 \mathrm{~g} / \mathrm{L} \text { glucose), } \\
\text { dilution rates of } \\
0.05 / \mathrm{h} \text { and } 0.1 / \mathrm{h}\end{array}$ & Continuous & {$[61]$} \\
\hline
\end{tabular}


Table 3. Cont.

\begin{tabular}{|c|c|c|c|c|c|c|c|c|c|c|c|c|}
\hline Group & Product & $\begin{array}{c}\text { Titer } \\
(\mathrm{mg} / \mathrm{L})\end{array}$ & Carbon Source & $\begin{array}{l}\text { Nitrogen } \\
\text { Source }\end{array}$ & $\mathrm{pH}$ & ${ }^{\circ} \mathrm{C}$ & $\begin{array}{c}\text { Aeration } \\
\text { /Agitation }\end{array}$ & $\begin{array}{c}\text { Dissolved } \\
\text { Oxygen }\end{array}$ & $\begin{array}{l}\text { Inoculum } \\
\text { Size }\end{array}$ & $\begin{array}{l}\text { Feeding } \\
\text { Strategy }\end{array}$ & $\begin{array}{c}\text { Operation } \\
\text { Mode }\end{array}$ & References \\
\hline \multirow{3}{*}{ 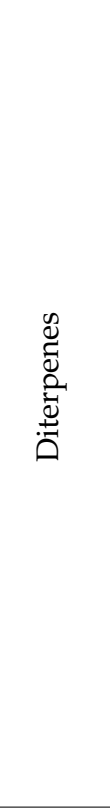 } & Geranylgeraniol & 3310 & $\begin{array}{l}\text { Initial } 1 \mathrm{~g} / \mathrm{L} \\
\text { glucose, then sole } \\
\text { glucose and } \\
\text { glucose/ethanol } \\
\text { mix. feeding }\end{array}$ & $\begin{array}{c}\left(\mathrm{NH}_{4}\right)_{2} \mathrm{SO}_{4} \\
\text { corn } \\
\text { steep liquor }\end{array}$ & 5.5 & 33 & $\begin{array}{l}900 \mathrm{rpm} / \\
1 \mathrm{vvm}\end{array}$ & - & - & $\begin{array}{c}\text { Glucose }(50 \% \\
\text { wt/v) and then } \\
\text { glucose/ethanol } \\
(25 \% \mathrm{wt} / \mathrm{v} / 50 \% \\
v / v) \text { feeding (rate } \\
\text { of } 5.8 \mathrm{~g} / \mathrm{h})\end{array}$ & Fed-Batch & [89] \\
\hline & Miltiradiene & 488 & $\begin{array}{c}\text { Initial } 20 \mathrm{~g} / \mathrm{L} \\
\text { glucose, then feed } \\
\text { solution(glucose, } \\
\text { other nutrients and } \\
\text { ingredients) }\end{array}$ & $\begin{array}{l}\text { Peptone. } \\
\text { Yeast } \\
\text { extract }\end{array}$ & 5.5 & 30 & $\begin{array}{l}600 \mathrm{rpm} / \\
5 \mathrm{~L} / \mathrm{h} \text { air }\end{array}$ & - & $\mathrm{OD}=0.05$ & $\begin{array}{c}\text { Feed solution } \\
\text { (glucose and other } \\
\text { nutrients) addition } \\
\text { by } 5 \mathrm{~mL} / \mathrm{h} \text { feed } \\
\text { rate. }\end{array}$ & Fed-Batch & [78] \\
\hline & $\begin{array}{l}\text { Oxygenated } \\
\text { taxanes }\end{array}$ & 33 & $\begin{array}{c}\text { Initial } 40 \mathrm{~g} / \mathrm{L} \\
\text { glucose or } 20 \mathrm{~g} / \mathrm{L} \\
\text { xylose }\end{array}$ & $\begin{array}{c}\left(\mathrm{NH}_{4}\right)_{2} \mathrm{HPO}_{4} \\
\text { Yeast } \\
\text { extract }\end{array}$ & 7.0 & $\begin{array}{c}30 \\
\text { and } \\
22\end{array}$ & $\begin{array}{c}280- \\
800 \mathrm{rpm} / \\
0.5 \mathrm{~L} / \mathrm{min}\end{array}$ & $30 \%$ & $\begin{array}{l}1 \% \text { for } E . \\
\text { coli and } 2 \% \\
\text { for } S . \\
\text { cerevisiae }\end{array}$ & $\begin{array}{l}\text { Pulse feeding by } \\
\text { carbon source } \\
\text { control }(20 \mathrm{~g} / \mathrm{L} \text { of } \\
\text { glucose feed when } \\
\text { glucose below } \\
20 \mathrm{~g} / \mathrm{L} \text { and } 50 \mathrm{~g} / \mathrm{L} \\
\text { xylose feed when } \\
\text { xylose conc. below } \\
10 \mathrm{~g} / \mathrm{L})\end{array}$ & $\begin{array}{l}\text { Fed-Batch } \\
\text { (co-culture) }\end{array}$ & [90] \\
\hline \multirow{3}{*}{ 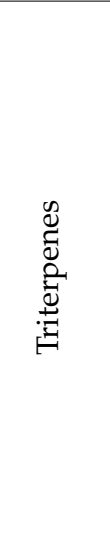 } & $\begin{array}{c}\text { Protopanaxadiol } \\
\text { and } \\
\text { dammarenediol- } \\
\text { II }\end{array}$ & $\begin{array}{l}1189 \\
\text { and } \\
1548\end{array}$ & $\begin{array}{l}\text { Initial } 25 \mathrm{~g} / \mathrm{L} \\
\text { glucose and then } \\
\text { glucose feeding }\end{array}$ & $\left(\mathrm{NH}_{4}\right)_{2} \mathrm{SO}_{4}$ & 5.5 & 30 & $\begin{array}{c}1000 \mathrm{rpm} / 5 \\
\mathrm{~L} / \mathrm{min} \text { air }\end{array}$ & - & $\mathrm{OD}=0.5$ & $\begin{array}{c}\text { Fed solution } \\
\text { (glucose and other } \\
\text { nutrients) addition } \\
\text { when ethanol } \\
\text { below } 0.5 \mathrm{~g} / \mathrm{L}\end{array}$ & Fed-Batch & [79] \\
\hline & $\beta$-amyrin & 139 & $\begin{array}{l}\text { Initial } 20 \mathrm{~g} / \mathrm{L} \\
\text { glucose and then } \\
\text { pulse ethanol } \\
\text { feeding }\end{array}$ & $\left(\mathrm{NH}_{4}\right)_{2} \mathrm{SO}_{4}$ & - & 30 & $1 \mathrm{vvm}$ & - & $\mathrm{OD}=0.2$ & $\begin{array}{c}\text { Pulse ethanol } \\
(5 \mathrm{~g} / \mathrm{L}) \text { feeding at } \\
\text { every } 12 \mathrm{~h}\end{array}$ & Fed-Batch & {$[71]$} \\
\hline & $\beta$-amyrin & 108 & $\begin{array}{l}\text { Initial } 20 \mathrm{~g} / \mathrm{L} \\
\text { dextrose, and then } \\
\text { pulse glucose } \\
\text { feeding }\end{array}$ & $\begin{array}{c}\text { Yeast } \\
\text { extract } \\
\text { Peptone }\end{array}$ & 6.0 & 30 & - & - & - & $\begin{array}{l}\text { Pulse glucose } \\
(5 \mathrm{mg} / \mathrm{L}) \text { feeding } \\
\text { at every } 12 \mathrm{~h}\end{array}$ & Fed-Batch & [85] \\
\hline
\end{tabular}


Table 3. Cont.

\begin{tabular}{|c|c|c|c|c|c|c|c|c|c|c|c|c|}
\hline Group & Product & $\begin{array}{c}\text { Titer } \\
(\mathrm{mg} / \mathrm{L})\end{array}$ & Carbon Source & $\begin{array}{c}\text { Nitrogen } \\
\text { Source }\end{array}$ & $\mathrm{pH}$ & ${ }^{\circ} \mathrm{C}$ & $\begin{array}{l}\text { Aeration } \\
\text { /Agitation }\end{array}$ & $\begin{array}{c}\text { Dissolved } \\
\text { Oxygen }\end{array}$ & $\begin{array}{l}\text { Inoculum } \\
\text { Size }\end{array}$ & $\begin{array}{l}\text { Feeding } \\
\text { Strategy }\end{array}$ & $\begin{array}{c}\text { Operation } \\
\text { Mode }\end{array}$ & References \\
\hline & $\begin{array}{l}\text { Betulinic } \\
\text { acid }\end{array}$ & 182 & $\begin{array}{l}\text { Initial } 50 \mathrm{~g} / \mathrm{L} \\
\text { glucose and then } \\
\text { pulse ethanol } \\
\text { feeding }\end{array}$ & $\mathrm{NH}_{4} \mathrm{Cl}$ & 6.0 & 30 & $1 \mathrm{vvm}$ & $>30 \%$ & $\begin{array}{c}\mathrm{Xi}^{2}=0.08 \\
\mathrm{~g} / \mathrm{L}\end{array}$ & $\begin{array}{c}\text { Pulse ethanol } \\
(25 \mathrm{~g} / \mathrm{L}) \text { feeding } \\
\text { control with DO } \\
\text { spikes }\end{array}$ & Fed-Batch & [75] \\
\hline & $\begin{array}{c}\text { Ginsenoside } \\
\text { Rh2 }\end{array}$ & 2250 & $\begin{array}{l}\text { Initial } 25 \mathrm{~g} / \mathrm{L} \\
\text { glucose and then } \\
\text { glucose feeding }\end{array}$ & $\begin{array}{c}\text { Yeast } \\
\text { extract } \\
\text { Peptone }\end{array}$ & 5.0 & 30 & - & $>30 \%$ & $11 \%$ & $\begin{array}{l}\text { Fed solution (glucose } \\
\text { and other nutrients) } \\
\text { addition when } \\
\text { ethanol below } \\
0.5 \mathrm{~g} / \mathrm{L}\end{array}$ & Fed-Batch & [35] \\
\hline
\end{tabular}

${ }^{1}$ Initial optical density (OD); ${ }^{2}$ Initial biomass (Xi); “-" Not described. 


\subsection{Nitrogen Source}

S. cerevisiae is able to utilize different kinds of nitrogen containing compounds in their natural habitat, such as amino acids, ammonium ions $\left(\mathrm{NH}_{4}{ }^{+}\right)$, peptides, and urea. When these compounds are present in the growth medium, they are transported into the cells by permeases and used as building blocks in biochemical pathways or catabolized into glutamate and ammonium for nitrogen metabolism [91]. The type and concentration of nitrogen sources affect the growth and gene expression in this yeast. S. cerevisiae uses preferentially good nitrogen sources, such as ammonia, glutamine, and asparagine, over poor ones, such as proline and urea. Growth rate of this yeast is relatively high in good nitrogen sources rather than in poor nitrogen sources [92]. The accumulation of yeast biomass strongly depends on the nitrogen content in the growth medium, since it was reported that the proportion of nitrogenous compounds in yeast cells is about $50 \%$ (by weight) [93]. The most used nitrogen sources for terpenoid production are ammonium sulfate $\left(\left(\mathrm{NH}_{4}\right)_{2} \mathrm{SO}_{4}\right)$, ammonium dihydrogen phosphate $\left(\left(\mathrm{NH}_{4}\right) \mathrm{H}_{2} \mathrm{PO}_{4}\right)$, ammonium chloride $\left(\mathrm{NH}_{4} \mathrm{Cl}\right)$, yeast extract, peptone, tryptone, and sometimes combination of those (Table 3). Higher terpene concentrations were achieved when $\left(\mathrm{NH}_{4}\right)_{2} \mathrm{SO}_{4}$ was used as nitrogen source (Table 3). On the other hand, nitrogen limited resting cell fermentation enhanced the titer of betulunic acid (from 57 to $182 \mathrm{mg} / \mathrm{L}$ ) and total triterpenoid concentration (from 319 to $854 \mathrm{mg} / \mathrm{L}$ ) [75]. In this study, the $\mathrm{NH}_{4} \mathrm{Cl}$ concentration was decreased from $2.8 \mathrm{~g} / \mathrm{L}$ to $0.939 \mathrm{~g} / \mathrm{L}$ to allow nitrogen starvation. It was considered that restriction of biomass synthesis by nitrogen limitation might support the flux into terpenoid accumulation, since terpenoid synthesis has to compete for carbon, energy, and redox cofactors throughout yeast growth [94]. However, under this condition, cessation of growth and product formation, and lower specific productivity were observed in extended fermentations [75]. This indicates decrease in cell viability due to accumulation of toxic intermediates, or reactive oxygen species, which was also reported in the production of farnesene and artemisinic acid $[27,95]$. Deficiency of nitrogen content in prolonged fermentations can also result in sluggish or stuck fermentation. However, high nitrogen concentrations also carry risks to the process, once it may overstimulate yeast reproduction and increase biomass levels too fast, resulting in shortage of other yeast nutrients, increased fermentation temperatures and, eventually, causing stuck fermentations and productivity losses. Thus, prolonging the release of nitrogen sources under tight control during the fermentation process can be a good strategy to extend the fermentation period, without heat peaks and productivity breaks $[96,97]$.

\section{4. $\mathrm{pH}$}

In general, as an acidophilic organism, S. cerevisiae grows better under acidic conditions, in the $\mathrm{pH}$ range from 4 to 6 , depending on the temperature, the presence of oxygen, and the strain [98]. The $\mathrm{pH}$ range between 5 and 6 has been mainly employed for terpenoid production (Table 3). In the study by [75], it was shown that fermentation time was reduced in batch cultivation at $\mathrm{pH} 6$, while total terpenoid productivity decreased. Moreover, precipitation of solid particles, containing insoluble crystals and good quantity of triterpenoids on the inner wall of bioreactor was observed. The solubility of many terpenoids, especially hydrophobic triterpenoids, is $\mathrm{pH}$-dependent, being higher at alkaline $\mathrm{pH}$ values, decreasing at lower $\mathrm{pH}$ values [99]. In another study, alkaline medium with $\mathrm{pH}$ ranging from 7 to 8 enhanced farnesol accumulation by S. cerevisiae [100]. It was also reported that the optimum $\mathrm{pH}$ for the wild type $S$. cerevisiae, and mutant strain in isopentenyl diphosphate isomerase activity (one of the important rate-limiting enzymes in terpenoid production), was 7.5 [101]. Alkaline $\mathrm{pH}$ might enhance the synthesis and solubility of terpenoids in the cultivation medium, but growth and biomass accumulation might be low, not allowing high cell density cultivation as desirable in industrial terpenoids production. 


\subsection{Temperature}

The most used incubation temperature in terpenoid production is $30^{\circ} \mathrm{C}$. Rarely, $28^{\circ} \mathrm{C}$ and $33^{\circ} \mathrm{C}$ had also been employed, such as in the synthesis of geraniol and geranylgeraniol by S. cerevisiae, respectively (Table 3 ). In a study of the effects of fermentation temperature on $S$. cerevisiae, the highest population was achieved at $30^{\circ} \mathrm{C}$, while at lower temperatures, it was reached later [102]. In contrast, at high temperatures, especially at $35^{\circ} \mathrm{C}$, cell viability decreased [102]. High temperatures cause yeast stress, and, thus, such a condition is not favorable for its growth. As a response to the high temperature, heat-shock proteins are synthesized, and ribosome is inactivated. Different enzymes responsible for many microbial activities are also sensitive to high temperatures and are usually inactivated in this harsh condition [103]. Moreover, the role of temperature in (+)-valencene accumulation was investigated and found that remarkable enhancement in (+)-valencene concentration at $25^{\circ} \mathrm{C}(87.2 \mathrm{mg} / \mathrm{L})$ was observed compared to at $30^{\circ} \mathrm{C}(20.6 \mathrm{mg} / \mathrm{L})$ [21]. The benefit of lowering the temperature in the production of other relevant pharmaceuticals in yeast has also been previously reported in the case of plant lectins expression in Pichia pastoris $[104,105]$.

\subsection{Dissolved Oxygen}

Under aerobic conditions, yeast converts glucose to carbon dioxide and water to produce energy. However, at high glucose concentrations, it also produces ethanol from glucose, which is known as the "Crabtree effect". In yeast cultivation, the biomass increases very fast in the exponential phase, accompanying with high amount of oxygen consumption, so dissolved oxygen (DO) decreases quickly. Simultaneously, ethanol is produced because of the Crabtree effect. When glucose concentration decreases to a relatively low level, growth of yeast cells slows down due to inadequate carbon source in the medium; therefore, the DO increases promptly. If the glucose is added to culture medium, DO will again slowly decrease with the consumption of glucose. Thus, this approach of controlling DO plays an important role on cell growth and product formation, especially in fed-batch fermentations. The optimum glucose consumption rate and the yeast growth rate can be tightly controlled by the DO [106]. In a study for ergosterol production by fed-batch fermentation of $S$. cerevisiae, DO was a significant factor in its production and highest yield was obtained when DO was kept at $12 \%$, explaining that the accumulation of this sterol was oxygen dependent [106]. Although oxygen is a vital component for aerobic organisms, it can also be a toxic agent that can damage cells by the action of reactive oxygen species (ROS). ROS can be generated through many different stress conditions, including high oxygen content in the culture medium [107]. Because of this, selection of the optimum DO level during terpenoid fermentation has significant effect on health and growth of cells as well as product formation. In many studies of terpenoid production, DO levels were kept above $30 \%$, or $40 \%$, by controlling agitation and aeration (cascade mode) in fed-batch processes (Table 3). During stationary phase of cultivation, DO levels reached up to $1.5 \%$, which maintain micro aerobic fermentation in order to drive metabolic flux towards the production of fermentative products, like terpenoids [108].

\subsection{Inoculum Size}

The size of inoculum used for terpenoid production is generally applied between $2.5 \%$ and $14 \%$ of medium volume or initial optical density $\left(\mathrm{OD}_{600}\right)$ of 0.05 to 0.5 is used instead (Table 3). For instance, in a study for optimization of $\beta$-amyrin formation by engineered yeast in fed-batch fermentation, the most favorable inoculum size was reported as initial $\mathrm{OD}_{600}$ of 0.3 [109]. Moreover, in another study, inoculum size of 5.0 and $5.2 \%(v / v)$ with S. cerevisiae strain BY4741 and 8.1 and $2.6 \%(v / v)$ for strain EGY48 were favorable for squalene production in semi-anaerobic shake flask fermentations [110]. According to these results, optimum inoculum size was strain dependent. The difference between the productivity of these two strains at high inoculum size might be related with the synthesis of higher ergosterol by strain EGY48, which enhances tolerance to ethanol, which is produced during the early stages of fermentation, and which could be used as a substrate 
for squalene production under glucose depletion at the late stage of fermentation [110]. A reasonable high volume of inoculum is required to minimize the length of lag phase, increase specific growth rate, and accumulate the maximum biomass in the production fermenter in a shorter time as possible, which helps to achieve highest productivity. A study for inoculum size effect on metabolic regulation and stress response of $S$. cerevisiae in high cell density fermentation showed that as inoculum size (40 g/L initial biomass) increased, stress protectants (glycerol and proline) in glycerol biosynthesis and amino acid metabolism improved. However, citric acid cycle (TCA) intermediates are depressed and metabolites (myo-inositol and ethanolamine) associated with membrane structure and function decreased [111]. In the same study, growth rate, glucose consumption rate and ethanol productivity increased in high inoculum size, which is convenient for industrial ethanol fermentation. However, very high inoculum size will cause the rapid depletion of nutrients and oxygen, which results in microaerobic condition and increased oxygen demand. High ethanol production in anaerobic condition might have toxic effects on yeast cells and be the reason for the decrease in terpenoid yield. Low inoculum size causes longer fermentation phases, lower productivity parameters, and high risk of contamination. However, optimum inoculum size can help the culture to grow at extreme conditions, such as high salt concentrations and $\mathrm{pH}$ ranges $[112,113]$.

\section{Modes of Fermentation Process}

Batch, fed-batch, and continuous fermentation process have all been used in terpenoids production. In the batch type of operation, required nutrients, feedstock, other ingredients, and microorganism are added to fermentation tank at the beginning of fermentation, while in the fed-batch type, some nutrients and ingredients are added to tank at certain intervals of time. In the continuous type of operation, input materials (nutrients and ingredients) are continuously fed and output materials (culture broth) are simultaneously removed from fermentation tank $[83,103]$. The choice of the most effective operation mode for terpenoids production depends on the fermentative properties of microorganism (e.g., kinetics, toxicity tolerance, lifespan), as well as the feedstock nature (e.g., sterilization, preparation, concentrations).

Although metabolic engineering strategies, and pathways improvement, are employed to enhance terpenoids expression, high cell density cultivation is needed to obtain high product titers, yield, and productivity for industrial processes. For high cell density cultivation, it is also important to choose an optimum method of reactor operation, since environmental conditions affect the growth and product formation. Among these conditions, nutrient and substrate concentrations are important to be kept in specific ranges to avoid overfeeding or underfeeding [114].

\subsection{Batch Mode}

Batch operation mode is the simplest and easiest process since it requires low cost, low labor work, less control, as well as easy sterilization and preparation of feedstock [103]. Thus, it is usually preferred due to the practicability of recovery, which needs no remaining substrate in the fermentation broth [115]. Many works on terpenoid biosynthesis by engineered S. cerevisiae strains were performed in batch fermentation, mainly in flask assays. For instance, monoterpenes, such as limonene [80,81], geraniol [88], and sabinene [70] were produced in shake flask fermentations by engineered S. cerevisiae strains in the range between 0.49 and $17.5 \mathrm{mg} / \mathrm{L}$ (Table 3). Moreover, a biosynthetic alternative to D2 diesel (gasoil), sesquiterpene bisabolone, was accumulated by more than $900 \mathrm{mg} / \mathrm{L}$ in shake flask fermentation [66]. More recently, other sesquiterpenes, nerolidol [19] and the sedative valerenic acid [82], and polpunonic acid [20], the precursor of the anti-obesity agent diterpene celastrol, have been produced in the range between 1.4 and $336.5 \mathrm{mg} / \mathrm{L}$ by highly engineered strains in shake flask fermentations. Concerning batch fermentations in a bioreactor, one example was the production of (S)-linalool, which was accumulated in a tank at $0.26 \mathrm{mg} / \mathrm{L}$ [68]. 
Interestingly, immobilized cell method (ICM) was employed for improving production of some terpenes in flask assays. Immobilized cells prepared by agarose entrapment and free cells (FCM) of S. cerevisiae were compared in shake flask fermentations for citronellol production [116]. It was observed that ICM yielded the main product, citronellol (48.5\%), whereas FCM accumulated more products along with citronellol, which just yielded $24.2 \%$ and $27.2 \%$ at incubation time of 6 and 15 days, respectively [116]. Higher citronellol production by ICM was explained by possible improvement of specific metabolic activities [117].

Although batch fermentation has several advantages, as explained above, some limitations also exist. The main disadvantage is the growth inhibition of microorganism due to product toxicity, especially in the production of monoterpenes. This problem can only be overcome by continuous removal of the inhibitor product (e.g., limonene) from culture during fermentation, for example, by a two-phase system or by headspace removal [54]. Alternatively, fed-batch fermentation with daily broth draw can be employed.

\subsection{Fed-Batch Mode}

Fed-batch mode is the mostly used operation in the industrial production of diverse type of products as it combines the advantages of both batch and continuous fermentations [103,118]. It has some advantages over batch mode, such as less inhibitory effect of higher accumulated product and feedstock concentration, higher product formation, extended lifespan of cells, maximum cell viability, and easy control of several important physiochemical factors such as temperature, $\mathrm{pH}$, and oxygen saturation [103,119]. Other relevant advantages are the possibility of attaining of high cell density, leading to high product formation, and daily product availability. It is generally considered that fed-batch mode with intermittent removal of product and feeding of feedstock when leftover nutrients are exhausted, is the most effective operation mode for terpenoids since these products become less toxic within this approach. In addition, this process can achieve the highest volumetric productivity. The most critical parameter in the fed-batch mode is the optimization of feeding since it plays an important role for increasing product yield and productivity [83].

Many pharmaceutical terpenoids have been produced by fed-batch fermentation (Table 3). The monoterpenes, geraniol [69,73] and limonene [72], produced by engineered S. cerevisiae strains, have achieved the titer of $1.69 \mathrm{~g} / \mathrm{L}$ and $0.918 \mathrm{~g} / \mathrm{L}$, respectively, with glucose/ethanol mixture or pure ethanol feeding in fed-batch fermentations. These values were quite low (3 to 6-fold lower) when batch fermentations were employed in the same studies. In these works, two strategies were applied to improve productivity of monoterpenes during fed-batch fermentation. Firstly, a two-phase fermentation system was employed using the nontoxic extractive solvents dodecane and isopropyl myristate to alleviate the toxicity of geraniol and limonene. Then, the dynamic control of ERG20 was attempted by replacing ERG20 promoter with the glucose sensing HXT1 promoter, which is stronger in the presence of glucose and weaker in the absence of glucose. Thus, replacement of HXT1 promoter provided the diauxic fermentation process, where glucose was consumed during cell growth with ethanol production, which was then used for monoterpenes biosynthesis. This approach improved the productivity of geraniol and limonene when glucose/ethanol (1/7), or pure ethanol, were fed instead of glucose as sole carbon source during fed-batch fermentations $[69,72]$, indicating that the dynamic control of ERG20 by HXT1 promoter could provide flux distribution between cell growth and monoterpene synthesis in the absence or presence of low glucose. Moreover, pure ethanol feeding enhanced monoterpene production, since it supplies direct Acetyl-CoA precursors.

Apart from monoterpenes, great improvement in the production of sesquiterpenes has been achieved using fed-batch processes. For instance, titers of artesiminin precursors amorpha-4,11-diene [60] and artemisinic acid [27] have reached $>40 \mathrm{~g} / \mathrm{L}$ and $25 \mathrm{~g} / \mathrm{L}$, respectively, in fed-batch fermentations using highly engineered $S$. cerevisiae. In these studies, the exponential feeding rate for glucose/ethanol mixture substrate feeding and pulse feeding for ethanol substrate $(10 \mathrm{~g} / \mathrm{L})$ were applied and feeding algorithms were automatically triggered through responses of stir rate, DO percentage as well as evaluation 
of $\mathrm{CO}_{2}$ rate $[27,60]$. As extracting solvents, isopropyl myristate and methyl oleate were used for artemisinic acid and amorpha-4,11-diene extractions from fermentation broth, respectively [27,60]. Ref. [60] deleted the GAL1, GAL10, and GAL7 gene cluster, as well as GAL80, to prevent galactose use, which is an expensive inducer, in the production of amorpha-4,11-diene. In this attempt, low level of galactose was required to induce production at the end of batch phase of glucose limited fed-batch fermentation. In addition, same authors applied phosphate limited fed-batch fermentation, which could limit growth of cells and channel carbon flux to product formation, ending up with more than 2 times of amorpha-4,11-diene production. Finally, ethanol-restricted fed-batch fermentation was improved, resulting in $37 \mathrm{~g} / \mathrm{L}$ of amorpha-4,11-diene, which was lower than ethanol unrestricted fed-batch fermentation but this process required lower levels of oxygen uptake rate (OUR), what is desired and feasible for industrial scale fermentation. On the other hand, ref. [27] used isopropyl myristate solvent to extract artemisinic acid from fermentation and improved its productivity in fed-batch fermentations. With this method, a significant enhancement on titer and yield was observed by eliminating successfully the acid from the aqueous phase, since artemisinic acid precipitated in fermentation broth, complicating sampling and negatively affecting viability of cells. Other pharmaceutical sesquiterpenes, such as bisabolene [76], nerolidol [84], patchoulol [22], zerumbone [77], and $\alpha$-humulene [4] were accumulated by engineered $S$. cerevisiae strains with titers of $5.2 \mathrm{~g} / \mathrm{L}, 5.5 \mathrm{~g} / \mathrm{L}, 0.467 \mathrm{~g} / \mathrm{L}, 0.040 \mathrm{~g} / \mathrm{L}$ and $1.7 \mathrm{~g} / \mathrm{L}$, respectively, in fed-batch fermentations. Constant feeding rate triggered by $\mathrm{pH}$ rises was used in bisabolene production of glucose fed-batch fermentation [76] while pulse feeding, which was programmed using script controller feeding and triggered by DO spikes, was performed in nerolidol production [84]. Moreover, carbon-source controlled three-stage fed-batch fermentation was employed for patchoulol production [22], whereas in zerumbone and $\alpha$-humulene production, constant feed rate triggered by $\mathrm{DO}$ and $\mathrm{pH}$ rises was applied [4,77]. In these studies, combination of constitutive copper-inducible and diauxic-induced transcription regulation patterns was employed to improve nerolidol production in the fed-batch fermentation through enhancing the growth rates in each phase (exponential, ethanol growth, and diauxic phases) and productivities after the diauxic shift. Thus, combined system yielded better nerolidol titer in the carbon-overflow fed-batches than substrate restricted-fed batches. The improvement in nerolidol productivity might be due to MVA pathway response to "overflow" metabolism, as is seen in ethanol/acetate/glycerol production through glycolysis [84]. Moreover, a carbon source controlled three stages fermentation (first stage: high glucose concentration feeding; second stage: lower concentration of glucose and glycerol feeding; third stage: ethanol feeding) was used to balance the trade-off between the competitive squalene and patchoulol pathways in the production of patchoulol by engineered S. cerevisiae [22].

The pharmaceutical diterpenes, geranylgeraniol [89], miltiradiene [78], and oxygenated taxanes (precursors of paclitaxel) [90] were also accumulated $(3.31 \mathrm{~g} / \mathrm{L}, 0.488 \mathrm{~g} / \mathrm{L}$ and $0.033 \mathrm{~g} / \mathrm{L}$, respectively) by genetically modified $S$. cerevisiae strains (co-culture with $E$. coli in oxygenated taxanes accumulation) in fed-batch fermentations. In these studies, after depletion or decrease of substrate in the medium, feed rates of $5.6 \mathrm{~g} / \mathrm{h}$ of glucose/ethanol mixture for geranylgeraniol, $5 \mathrm{~mL} / \mathrm{h}$ of glucose and other ingredients for miltiradiene, and feed pulses of $20 \mathrm{~g} / \mathrm{L}$ glucose and $50 \mathrm{~g} / \mathrm{L}$ xylose for oxygenated taxanes productions were applied.

In addition, several triterpenes and their precursors, such as protopanaxadiol $(1.189 \mathrm{~g} / \mathrm{L})$ and dammarenediol-II (1.548 g/L) [79], $\beta$-amyrin $(0.139 \mathrm{~g} / \mathrm{L}$ and $0.108 \mathrm{~g} / \mathrm{L})([71,85]$, respectively), betulinic acid $(0.182 \mathrm{~g} / \mathrm{L})$ [75] and ginsenoside $\mathrm{Rh} 2(2.25 \mathrm{~g} / \mathrm{L})$ [35] were attempted to accumulate and successfully produced in fed-batch fermentations. In these studies, distinct feeding strategies were applied. For protopanaxadiol, dammarenediol-II, and ginsenoside Rh2, glucose was fed when ethanol concentration was less than $0.5 \mathrm{~g} / \mathrm{L}$, for $\beta$-amyrin, glucose at $5 \mathrm{mg} / \mathrm{L}$ was fed every $12 \mathrm{~h}$, and for betulinic acid, pulsed glucose and continuous ethanol feeding, controlled by DO signal with ethanol response, was adopted. Highest betulinic acid titer was achieved by excess ethanol feeding, following 
with nitrogen-limited resting cell fed-batch fermentation [75]. The improvement in this fermentation was possibly due to the increased supply of the precursor acetyl-CoA, or the redox cofactor NADPH, of which 18 and 17 mol were needed for production of 1 mol of betulinic acid [75]. In the same study, solid liquid extraction using polar solvents such as, acetone or ethyle acetate, and subsequent precipitation with strong acid, was applied to recover lupane-type triterpenoids with high selectivity and yield.

It can be deduced from these works that different feeding strategies in fed-batch fermentation depend on the response of engineering strains used and their genetic design, such as the choice of promoters. This is because each strain can have different kind of promoters regulating heterologous gene expression in terpenoids pathway, which may influence the substrate type and the concentrations to be employed in the culture medium. Namely, modifications in inducible gal-promoters and constitutive promoters such as PGPD (glyceraldehyde-3-phosphate), PTEF1 (translational elongation factor), PADH1 (alcohol dehydrogenase), PPGK1 (phosphoglycerate kinase), and uptake control mutations, were reported to affect the feeding strategies in fed-batch terpenoids production [57].

\subsection{Continuous Mode}

Continuous processes (or chemostat cultivations) have been employed in industrial bioprocesses (e.g., insulin production) and have several advantages over batch and fedbatch, such as decreased costs of bioreactor constructions, minimized plant maintenance and operation costs, convenient bioprocess control, requirement of less downtime for tank cleaning and maintenance, and higher productivities $[83,103]$. One important advantage of this process is to provide a precise comparison of productivities of selected engineered strains under constant conditions and to investigate the effect of the growth rate independently of the other parameters [61]. However, only some studies have applied chemostat cultivation for terpenoid production. Ref. [61] employed continuous cultivation and achieved $\alpha$-santalene productivity of $0.036 \mathrm{Cmmol} /(\mathrm{g}$ biomass $) / \mathrm{h}$ at the dilution rate of $0.05 \mathrm{~h}^{-1}$. In another study, squalene accumulation of $30 \mathrm{mg} / \mathrm{g}$ (product/dry cell weight) was obtained at low dilution rates between $0.05 \mathrm{~h}^{-1}$ and $0.20 \mathrm{~h}^{-1}$ in glucose limited chemostat cultivation [120]. Despite demonstrated applicability in terpenoids production, continuous fermentation has been poorly explored, mainly because fed-batch fermentation has been shown to be the most effective way for obtaining meaningful terpene titers for industry, combining the advantages of batch and continuous mode at once.

\section{Conclusions and Future Perspective}

Pharmaceutical terpenoid production has attracted increasing attention in recent years because these compounds play significant roles in the prevention and treatment of different types of diseases. As the world's mortality rate rises, due to the incidence of severe diseases, such as cancer and malaria, the demand for these products increases, and, thus, fast development of alternative and sustainable sources rather than natural and chemical ones is required. Microbial fermentation of these special compounds promises a sustainable, cost effective, and high yield method in contrast to traditional methods. $S$. cerevisiae has been proven to be an efficient cell factory for large-scale terpenoid production. Industrial production of artemisinic acid and $\beta$-farnesene are examples of success.

Process optimization by screening different fermentation strategies is essential to improve TYP of pharmaceutical terpenoids, along with fine-tuning metabolic engineering in S. cerevisiae, as this yeast cannot produce target terpenoids naturally. Commercial terpenoid application is only possible with successful combination of these two fields, metabolic engineering and fermentation process development. Process optimization can increase productivity and reduce the cost of production by improving medium composition, physicochemical conditions, and applying efficient downstream processing. Most of the terpenoid titers obtained are in $\mathrm{mg}$ /L levels, mainly in batch fermentations, which do not have commercial meaning. On the other hand, bioreactor fermentation with fed-batch operation mode can provide titers at $\mathrm{g} / \mathrm{L}$ scale, and high productivities, while alleviating 
the toxicity of final product, which constitutes the most promising approach for industrial production of pharmaceutical terpenoids. Among factors affecting terpenoids fermentation, the $\mathrm{pH}$ and $\mathrm{DO}$ are relevant factors for certain production cases. Although $\mathrm{pH}$ range between 4 and 6 is optimal for yeast growth, and achieve high cell density, some terpenes can be insoluble under this condition, which might complicate the downstream processing. However, this can be solved, for instance, by harvesting tanks at high $\mathrm{pH}$ by addition of base solution. The use of extraction agents during cultivation is an option to reduce the toxic effects of terpenes, but it brings extra costs to the process. This problem can be overcome by optimizing the feed strategy together with product removal in fed-batch fermentation. The DO is often used as a trigger in fed-batch process for the control of yeast growth and product formation. Optimum oxygen concentrations are required to balance yeast health and productivity, since low levels can minimize yeast capacity, while high levels can lead to oxidative stress, which can be toxic to cells. Similarly, high temperatures can decrease cell viability, while at low temperatures, high cell density is achieved later. Optimization of media ingredients is also of huge importance as they can account for a significant part of the process costs. One way to decrease feedstock cost could be to find and adapt cheap carbon sources, like agricultural by-products, in S. cerevisiae metabolism, as extensively investigated in case of other biomolecules production, which also contributes to process sustainability. Indeed, the trend is for the increase of pharmaceutical terpenoids obtained through optimized fermentation. The power of synthetic biology tools and advances in metabolic engineering strategies for the introducing novel terpenoid biosynthesis pathways in S. cerevisiae will bring new opportunities to produce complex terpenes such as the current trend product "cannabinoids". The microbial fermentation of these highly promising and rare compounds at an affordable cost and high purity, independently from Cannabis plant cultivation, could absolutely support the pharmaceutical market, when the growing industrial demand for these products is foreseen.

Author Contributions: Conceptualization, E.C. and C.O.; investigation, E.C.; writing-original draft preparation, E.C.; writing-review and editing, C.O. and M.P.; supervision, C.O.; project administration, M.P.; funding acquisition, M.P. All authors have read and agreed to the published version of the manuscript.

Funding: This research was funded by Amyris Bio Products Portugal Unipessoal Lda and Escola Superior de Biotecnologia-Universidade Católica Portuguesa through Alchemy project-Capturing high value from industrial fermentation bio products (POCI-01-0247-FEDER-027578).

Acknowledgments: Alchemy Project (PT2020/POCI n. ${ }^{\circ}$ 27578), co-financed by Portugal 2020 under the Operational Programme for Competitiveness and Internationalization through the European Regional Development Fund (FEDER).

Conflicts of Interest: The authors declare no conflict of interest. The funders had no role in the design of the study; in the collection, analyses, or interpretation of data; in the writing of the manuscript, or in the decision to publish the results.

\section{References}

1. Christianson, D.W. Structural and Chemical Biology of Terpenoid Cyclases. Chem. Rev. 2017, 117, 11570-11648. [CrossRef] [PubMed]

2. Belcher, M.S.; Mahinthakumar, J.; Keasling, J.D. New frontiers: Harnessing pivotal advances in microbial engineering for the biosynthesis of plant-derived terpenoids. Curr. Opin. Biotechnol. 2020, 65, 88-93. [CrossRef] [PubMed]

3. Yang, W.; Chen, X.; Li, Y.; Guo, S.; Wang, Z.; Yu, X. Advances in Pharmacological Activities of Terpenoids. Nat. Prod. Commun. 2020, 15, 15. [CrossRef]

4. Zhang, C.; Li, M.; Zhao, G.-R.; Lu, W. Harnessing Yeast Peroxisomes and Cytosol Acetyl-CoA for Sesquiterpene $\alpha$-Humulene Production. J. Agric. Food Chem. 2020, 68, 1382-1389. [CrossRef] [PubMed]

5. Moser, S.; Pichler, H. Identifying and engineering the ideal microbial terpenoid production host. Appl. Microbiol. Biotechnol. 2019, 103, 5501-5516. [CrossRef]

6. Wang, Q.; Quan, S.; Xiao, H. Towards efficient terpenoid biosynthesis: Manipulating IPP and DMAPP supply. Bioresour. Bioprocess. 2019, 6, 6. [CrossRef] 
7. Zhang, Y.; Nielsen, J.; Liu, Z. Engineering yeast metabolism for production of terpenoids for use as perfume ingredients, pharmaceuticals and biofuels. FEMS Yeast Res. 2017, 17, 17. [CrossRef] [PubMed]

8. Bergman, M.E.; Davis, B.; Phillips, M.A. Medically Useful Plant Terpenoids: Biosynthesis, Occurrence, and Mechanism of Action. Molecules 2019, 24, 3961. [CrossRef]

9. Sharma, S.H.; Thulasingam, S.; Nagarajan, S. Terpenoids as anti-colon cancer agents-A comprehensive review on its mechanistic perspectives. Eur. J. Pharmacol. 2017, 795, 169-178. [CrossRef] [PubMed]

10. Krivoruchko, A.; Nielsen, J. Production of natural products through metabolic engineering of Saccharomyces cerevisiae. Curr. Opin. Biotechnol. 2015, 35, 7-15. [CrossRef] [PubMed]

11. Leavell, M.D.; McPhee, D.J.; Paddon, C.J. Developing fermentative terpenoid production for commercial usage. Curr. Opin. Biotechnol. 2016, 37, 114-119. [CrossRef]

12. Xiao, H.; Zhang, Y.; Wang, M. Discovery and Engineering of Cytochrome P450s for Terpenoid Biosynthesis. Trends Biotechnol. 2019, 37, 618-631. [CrossRef]

13. Benjamin, K.R.; Silva, I.R.; Cherubim, J.P.; McPhee, D.; Paddon, C.J. Developing Commercial Production of Semi-Synthetic Artemisinin, and of $\beta$-Farnesene, an Isoprenoid Produced by Fermentation of Brazilian Sugar. J. Braz. Chem. Soc. 2016, 27, 1339-1345. [CrossRef]

14. Zhu, L.; Chen, L. Progress in research on paclitaxel and tumor immunotherapy. Cell. Mol. Biol. Lett. 2019, 24, 1-11. [CrossRef] [PubMed]

15. Biggs, B.W.; Lim, C.G.; Saglinani, K.; Shankar, S.; Stephanopoulos, G.; De Mey, M.; Ajikumar, P.K. Overcoming heterologous protein interdependency to optimize P450-mediated Taxol precursor synthesis in Escherichia coli. Proc. Natl. Acad. Sci. USA 2016, 113, 3209-3214. [CrossRef] [PubMed]

16. Nandy, S.K.; Srivastava, R. A review on sustainable yeast biotechnological processes and applications. Microbiol. Res. 2018, 207, 83-90. [CrossRef] [PubMed]

17. Parapouli, M.; Vasileiadis, A.; Afendra, A.-S.; Hatziloukas, E. Saccharomyces cerevisiae and its industrial applications. AIMS Microbiol. 2020, 6, 1-32. [CrossRef] [PubMed]

18. Alexander, W.G. A history of genome editing inSaccharomyces cerevisiae. Yeast 2017, 35, 355-360. [CrossRef] [PubMed]

19. Qu, Z.; Zhang, L.; Zhu, S.; Yuan, W.; Hang, J.; Yin, D.; Tang, X.; Zheng, J.; Wang, Z.; Sun, J. Overexpression of the transcription factor HAC1 improves nerolidol production in engineered yeast. Enzym. Microb. Technol. 2020, 134, 109485. [CrossRef]

20. Hansen, N.L.; Miettinen, K.; Zhao, Y.; Ignea, C.; Andreadelli, A.; Raadam, M.H.; Makris, A.M.; Møller, B.L.; Stærk, D.; Bak, S.; et al. Integrating pathway elucidation with yeast engineering to produce polpunonic acid the precursor of the anti-obesity agent celastrol. Microb. Cell Factories 2020, 19, 1-17. [CrossRef] [PubMed]

21. Ouyang, X.; Cha, Y.; Li, W.; Zhu, C.; Zhu, M.; Li, S.; Zhuo, M.; Huang, S.; Li, J. Stepwise engineering of Saccharomyces cerevisiae to produce (+)-valencene and its related sesquiterpenes. RSC Adv. 2019, 9, 30171-30181. [CrossRef]

22. Ma, B.; Liu, M.; Li, Z.-H.; Tao, X.; Wei, D.-Z.; Wang, F.-Q. Significantly Enhanced Production of Patchoulol in Metabolically Engineered Saccharomyces cerevisiae. J. Agric. Food Chem. 2019, 67, 8590-8598. [CrossRef]

23. Wang, C.; Liwei, M.; Park, J.-B.; Jeong, S.-H.; Wei, G.; Wang, Y.; Kim, S.-W. Microbial platform for terpenoid production: Escherichia coli and Yeast. Front. Microbiol. 2018, 9, 2460. [CrossRef]

24. Zhuang, X.; Kilian, O.; Monroe, E.; Ito, M.; Tran-Gymfi, M.B.; Liu, F.; Davis, R.W.; Mirsiaghi, M.; Sundstrom, E.; Pray, T.; et al Monoterpene production by the carotenogenic yeast Rhodosporidium toruloides. Microb. Cell Factories 2019, 18, 1-15. [CrossRef]

25. Lin, P.-C.; Pakrasi, H.B. Engineering cyanobacteria for production of terpenoids. Planta 2019, 249, 145-154. [CrossRef] [PubMed]

26. Meadows, A.L.; Hawkins, K.M.; Tsegaye, Y.; Antipov, E.; Kim, Y.; Raetz, L.; Dahl, R.H.; Tai, A.; Mahatdejkul-Meadows, T.; Xu, L.; et al. Rewriting yeast central carbon metabolism for industrial isoprenoid production. Nat. Cell Biol. 2016, 537, 694-697. [CrossRef]

27. Paddon, C.J.; Westfall, P.J.; Pitera, D.J.; Benjamin, K.; Fisher, K.; McPhee, D.J.; Leavell, M.D.; Tai, A.; Main, A.; Eng, D.; et al. High-level semi-synthetic production of the potent antimalarial artemisinin. Nat. Cell Biol. 2013, 496, 528-532. [CrossRef] [PubMed]

28. Hill, P.; Benjamin, K.; Bhattacharjee, B.; Garcia, F.; Leng, J.; Liu, C.-L.; Murarka, A.; Pitera, D.; Porcel, E.M.R.; Da Silva, I.; et al. Clean manufacturing powered by biology: How Amyris has deployed technology and aims to do it better. J. Ind. Microbiol. Biotechnol. 2020, 47, 965-975. [CrossRef] [PubMed]

29. Ateba, S.B.; Mvondo, M.A.; Ngeu, S.T.; Tchoumtchoua, J.; Awounfack, C.F.; Njamen, D.; Krenn, L. Natural Terpenoids Against Female Breast Cancer: A 5-year Recent Research. Curr. Med. Chem. 2018, 25, 3162-3213. [CrossRef]

30. Jaeger, R.; Cuny, E. Terpenoids with Special Pharmacological Significance: A Review. Nat. Prod. Commun. 2016, 11, 1373-1390. [CrossRef] [PubMed]

31. Manayi, A.; Nabavi, S.M.; Daglia, M.; Jafari, S. Natural terpenoids as a promising source for modulation of GABAergic system and treatment of neurological diseases. Pharmacol. Rep. 2016, 68, 671-679. [CrossRef]

32. Xu, Y.F.; Lian, D.W.; Chen, Y.Q.; Cai, Y.F.; Zheng, Y.F.; Fan, P.L.; Ren, W.K.; Fu, L.J.; Li, Y.C.; Xie, J.H.; et al. In Vitro and In Vivo Antibacterial Activities of Patchouli Alcohol, a Naturally Occurring Tricyclic Sesquiterpene, against Helicobacter pylori Infection. Antimicrob. Agents Chemother. 2017, 61, e00122-17. [CrossRef] [PubMed]

33. Song, Y.; Xin, X.; Zhai, X.; Xia, Z.; Shen, K. Sequential combination of flavopiridol with Taxol synergistically suppresses human ovarian carcinoma growth. Arch. Gynecol. Obstet. 2014, 291, 143-150. [CrossRef] 
34. Carvalho, Â.; Hansen, E.H.; Kayser, O.; Carlsen, S.; Stehle, F. Designing microorganisms for heterologous biosynthesis of cannabinoids. FEMS Yeast Res. 2017, 17, 17. [CrossRef] [PubMed]

35. Wang, P.; Wei, W.; Ye, W.; Li, X.; Zhao, W.; Yang, C.; Li, C.; Yan, X.; Zhou, Z. Synthesizing ginsenoside Rh2 in Saccharomyces cerevisiae cell factory at high-efficiency. Cell Discov. 2019, 5, 1-14. [CrossRef] [PubMed]

36. Kim, J.H.; Yi, Y.-S.; Kim, M.-Y.; Cho, J.Y. Role of ginsenosides, the main active components of Panax ginseng, in inflammatory responses and diseases. J. Ginseng Res. 2017, 41, 435-443. [CrossRef]

37. Amiri, S.; Dastghaib, S.; Ahmadi, M.; Mehrbod, P.; Khadem, F.; Behrouj, H.; Aghanoori, M.-R.; Machaj, F.; Ghamsari, M.; Rosik, J.; et al. Betulin and its derivatives as novel compounds with different pharmacological effects. Biotechnol. Adv. 2020, 38, 107409. [CrossRef] [PubMed]

38. An, T.; Zha, W.; Zi, J. Biotechnological production of betulinic acid and derivatives and their applications. Appl. Microbiol. Biotechnol. 2020, 104, 3339-3348. [CrossRef] [PubMed]

39. Meshnick, S.R. Artemisinin: Mechanisms of action, resistance and toxicity. Int. J. Parasitol. 2002, 32, 1655-1660. [CrossRef]

40. Tu, Y. ChemInform Abstract: Artemisinin-A Gift from Traditional Chinese Medicine to the World (Nobel Lecture). Angew. Chem. Int. Ed. 2016, 47, 10210-10226. [CrossRef]

41. Creek, D.J.; Charman, W.N.; Chiu, F.C.K.; Prankerd, R.J.; Dong, Y.; Vennerstrom, J.L.; Charman, S.A. Relationship between Antimalarial Activity and Heme Alkylation for Spiro- and Dispiro-1,2,4-Trioxolane Antimalarials. Antimicrob. Agents Chemother. 2008, 52, 1291-1296. [CrossRef]

42. Efferth, T.; Dunstan, H.; Sauerbrey, A.; Miyachi, H.; Chitambar, C. The anti-malarial artesunate is also active against cancer. Int. J. Oncol. 2001, 18, 767-773. [CrossRef] [PubMed]

43. Appalasamy, S.; Lo, K.Y.; Ch'Ng, S.J.; Nornadia, K.; Othman, A.S.; Chan, L.-K. Antimicrobial Activity of Artemisinin and Precursor Derived fromIn VitroPlantlets ofArtemisia annuaL. BioMed Res. Int. 2014, 2014, 1-6. [CrossRef] [PubMed]

44. Kim, W.-S.; Choi, W.J.; Lee, S.; Kim, W.J.; Lee, D.C.; Sohn, U.D.; Shin, H.-S.; Kim, W. Anti-inflammatory, Antioxidant and Antimicrobial Effects of Artemisinin Extracts fromArtemisia annuaL. Korean J. Physiol. Pharmacol. 2014, 19, 21-27. [CrossRef] [PubMed]

45. Wohlfarth, C.; Efferth, T. Natural products as promising drug candidates for the treatment of hepatitis B and C. Acta Pharmacol. Sin. 2008, 30, 25-30. [CrossRef]

46. El-Sayed, E.-S.R.; Ahmed, A.S.; Hassan, I.A.; Ismaiel, A.A.; El-Din, A.-Z.A.K. Semi-continuous production of the anticancer drug taxol by Aspergillus fumigatus and Alternaria tenuissima immobilized in calcium alginate beads. Bioprocess. Biosyst. Eng. 2020, 43, 997-1008. [CrossRef] [PubMed]

47. Kiyama, R. Estrogenic terpenes and terpenoids: Pathways, functions and applications. Eur. J. Pharmacol. 2017, 815, 405-415. [CrossRef] [PubMed]

48. Russo, E.B. Taming THC: Potential cannabis synergy and phytocannabinoid-terpenoid entourage effects. Br. J. Pharmacol. 2011, 163, 1344-1364. [CrossRef]

49. Du Plessis, S.S.; Agarwal, A.; Syriac, A. Marijuana, phytocannabinoids, the endocannabinoid system, and male fertility. J. Assist. Reprod. Genet. 2015, 32, 1575-1588. [CrossRef]

50. Pertwee, R.G. Cannabinoid pharmacology: The first 66 years. Br. J. Pharmacol. 2006, 147, S163-S171. [CrossRef] [PubMed]

51. Luo, X.; Reiter, M.A.; D’Espaux, L.; Wong, J.; Denby, C.M.; Lechner, A.; Zhang, Y.; Grzybowski, A.T.; Harth, S.; Lin, W.; et al. Author Correction: Complete biosynthesis of cannabinoids and their unnatural analogues in yeast. Nat. Cell Biol. 2020, 580, E2. [CrossRef] [PubMed]

52. Ajikumar, P.K.; Tyo, K.; Carlsen, S.; Mucha, O.; Phon, T.H.; Stephanopoulos, G. Terpenoids: Opportunities for Biosynthesis of Natural Product Drugs Using Engineered Microorganisms. Mol. Pharm. 2008, 5, 167-190. [CrossRef] [PubMed]

53. Cho, M.; So, I.; Chun, J.N.; Jeon, J.-H. The antitumor effects of geraniol: Modulation of cancer hallmark pathways (Review). Int. J. Oncol. 2016, 48, 1772-1782. [CrossRef]

54. Jongedijk, E.; Cankar, K.; Buchhaupt, M.; Schrader, J.; Bouwmeester, H.; Beekwilder, J. Biotechnological production of limonene in microorganisms. Appl. Microbiol. Biotechnol. 2016, 100, 2927-2938. [CrossRef] [PubMed]

55. Chen, C.; Song, K.; Zhang, Y.; Chu, C.; Fan, B.; Song, Y.; Huang, H.; Chen, G. Biotransformation of betulinic acid by Circinella muscae and Cunninghamella echinulata to discover anti-inflammatory derivatives. Phytochemistry 2021, 182, 112608. [CrossRef] [PubMed]

56. Lyu, X.; Lee, J.; Chen, W.N. Potential Natural Food Preservatives and Their Sustainable Production in Yeast: Terpenoids and Polyphenols. J. Agric. Food Chem. 2019, 67, 4397-4417. [CrossRef] [PubMed]

57. Paramasivan, K.; Mutturi, S. Progress in terpene synthesis strategies through engineering of Saccharomyces cerevisiae. Crit. Rev. Biotechnol. 2017, 37, 974-989. [CrossRef] [PubMed]

58. Bian, G.; Deng, Z.; Liu, T. Strategies for terpenoid overproduction and new terpenoid discovery. Curr. Opin. Biotechnol. 2017, 48, 234-241. [CrossRef]

59. Urlacher, V.B.; Girhard, M. Cytochrome P450 monooxygenases: An update on perspectives for synthetic application. Trends Biotechnol. 2012, 30, 26-36. [CrossRef]

60. Westfall, P.J.; Pitera, D.J.; Lenihan, J.R.; Eng, D.; Woolard, F.X.; Regentin, R.; Horning, T.; Tsuruta, H.; Melis, D.J.; Owens, A.; et al. Production of amorphadiene in yeast, and its conversion to dihydroartemisinic acid, precursor to the antimalarial agent artemisinin. Proc. Natl. Acad. Sci. USA 2012, 109, E111-E118. [CrossRef] [PubMed] 
61. Scalcinati, G.; Partow, S.; Siewers, V.; Schalk, M.; Daviet, L.; Nielsen, J. Combined metabolic engineering of precursor and co-factor supply to increase $\alpha$-santalene production by Saccharomyces cerevisiae. Microb. Cell Factories 2012, 11, 117. [CrossRef] [PubMed]

62. Ignea, C.; Pontini, M.; Motawia, M.S.; Maffei, M.E.; Makris, A.M.; Kampranis, S.C. Synthesis of 11-carbon terpenoids in yeast using protein and metabolic engineering. Nat. Chem. Biol. 2018, 14, 1090-1098. [CrossRef]

63. Ignea, C.; Raadam, M.H.; Motawia, M.S.; Makris, A.M.; Vickers, C.E.; Kampranis, S.C. Orthogonal monoterpenoid biosynthesis in yeast constructed on an isomeric substrate. Nat. Commun. 2019, 10, 1-15. [CrossRef]

64. Hu, C.; Lu, W. Insight into yeast: A study model of lipid metabolism and terpenoid biosynthesis. Biotechnol. Appl. Biochem. 2014, 62, 323-328. [CrossRef] [PubMed]

65. Chen, X.; Zhang, C.; Lindley, N.D. Metabolic Engineering Strategies for Sustainable Terpenoid Flavor and Fragrance Synthesis. J. Agric. Food Chem. 2020, 68, 10252-10264. [CrossRef]

66. Peralta-Yahya, P.P.; Ouellet, M.; Chan, R.; Mukhopadhyay, A.; Keasling, J.D.; Lee, T.S. Identification and microbial production of a terpene-based advanced biofuel. Nat. Commun. 2011, 2, 483. [CrossRef]

67. Albertsen, L.; Chen, Y.; Bach, L.S.; Rattleff, S.; Maury, J.; Brix, S.; Nielsen, J.; Mortensen, U.H. Diversion of Flux toward Sesquiterpene Production inSaccharomyces cerevisiaeby Fusion of Host and Heterologous Enzymes. Appl. Environ. Microbiol. 2010, 77, 1033-1040. [CrossRef]

68. Deng, Y.; Sun, M.; Xu, S.; Zhou, J. Enhanced (S)-linalool production by fusion expression of farnesyl diphosphate synthase and linalool synthase in Saccharomyces cerevisiae. J. Appl. Microbiol. 2016, 121, 187-195. [CrossRef]

69. Zhao, J.; Li, C.; Zhang, Y.; Shen, Y.; Hou, J.; Bao, X. Dynamic control of ERG20 expression combined with minimized endogenous downstream metabolism contributes to the improvement of geraniol production in Saccharomyces cerevisiae. Microb. Cell Factories 2017, 16, 1-11. [CrossRef]

70. Ignea, C.; Pontini, M.; Maffei, M.E.; Makris, A.M.; Kampranis, S.C. Engineering Monoterpene Production in Yeast Using a Synthetic Dominant Negative Geranyl Diphosphate Synthase. ACS Synth. Biol. 2014, 3, 298-306. [CrossRef]

71. Zhang, G.; Cao, Q.; Liu, J.; Liu, B.; Li, J.; Li, C. Refactoring $\beta$-amyrin synthesis inSaccharomyces cerevisiae. AIChE J. 2015, 61, 3172-3179. [CrossRef]

72. Cheng, S.; Liu, X.; Jiang, G.; Wu, J.; Zhang, J.-L.; Lei, D.; Yuan, Y.-J.; Qiao, J.; Zhao, G.-R. Orthogonal Engineering of Biosynthetic Pathway for Efficient Production of Limonene in Saccharomyces cerevisiae. ACS Synth. Biol. 2019, 8, 968-975. [CrossRef]

73. Jiang, G.-Z.; Yao, M.-D.; Wang, Y.; Zhou, L.; Song, T.-Q.; Liu, H.; Xiao, W.-H.; Yuan, Y.-J. Manipulation of GES and ERG20 for geraniol overproduction in Saccharomyces cerevisiae. Metab. Eng. 2017, 41, 57-66. [CrossRef]

74. Zhao, F.; Du, Y.; Bai, P.; Liu, J.; Lu, W.; Yuan, Y. Enhancing Saccharomyces cerevisiae reactive oxygen species and ethanol stress tolerance for high-level production of protopanoxadiol. Bioresour. Technol. 2017, 227, 308-316. [CrossRef]

75. Czarnotta, E.; Dianat, M.; Korf, M.; Granica, F.; Merz, J.; Maury, J.; Jacobsen, S.A.B.; Förster, J.; Ebert, B.E.; Blank, L.M. Fermentation and purification strategies for the production of betulinic acid and its lupane-type precursors in Saccharomyces cerevisiae. Biotechnol. Bioeng. 2017, 114, 2528-2538. [CrossRef]

76. Özaydın, B.; Burd, H.; Lee, T.S.; Keasling, J.D. Carotenoid-based phenotypic screen of the yeast deletion collection reveals new genes with roles in isoprenoid production. Metab. Eng. 2013, 15, 174-183. [CrossRef]

77. Zhang, C.; Liu, J.; Zhao, F.; Lu, C.; Zhao, G.-R.; Lu, W. Production of sesquiterpenoid zerumbone from metabolic engineered Saccharomyces cerevisiae. Metab. Eng. 2018, 49, 28-35. [CrossRef]

78. Dai, Z.; Liu, Y.; Huang, L.; Zhang, X. Production of miltiradiene by metabolically engineeredSaccharomyces cerevisiae. Biotechnol. Bioeng. 2012, 109, 2845-2853. [CrossRef]

79. Dai, Z.; Liu, Y.; Zhang, X.; Shi, M.; Wang, B.; Wang, D.; Huang, L.; Zhang, X. Metabolic engineering of Saccharomyces cerevisiae for production of ginsenosides. Metab. Eng. 2013, 20, 146-156. [CrossRef]

80. Behrendorff, J.B.; E Vickers, C.; Chrysanthopoulos, P.; Nielsen, L.K. 2,2-Diphenyl-1-picrylhydrazyl as a screening tool for recombinant monoterpene biosynthesis. Microb. Cell Factories 2013, 12, 76. [CrossRef]

81. Jongedijk, E.; Cankar, K.; Ranzijn, J.; Van Der Krol, S.; Bouwmeester, H.; Beekwilder, J. Capturing of the monoterpene olefin limonene produced inSaccharomyces cerevisiae. Yeast 2014, 32, 159-171. [CrossRef]

82. Wong, J.; D’Espaux, L.; Dev, I.; van der Horst, C.; Keasling, J. De novo synthesis of the sedative valerenic acid in Saccharomyces cerevisiae. Metab. Eng. 2018, 47, 94-101. [CrossRef] [PubMed]

83. Bušić, A.; Marđetko, N.; Kundas, S.; Morzak, G.; Belskaya, H.; Šantek, M.I.; Komes, D.; Novak, S.; Šantek, B. Bioethanol Production from Renewable Raw Materials and its Separation and Purification: A Review. Food Technol. Biotechnol. 2018, 56, 289-311. [CrossRef]

84. Peng, B.; Plan, M.R.; Carpenter, A.; Nielsen, L.K.; Vickers, C.E. Coupling gene regulatory patterns to bioprocess conditions to optimize synthetic metabolic modules for improved sesquiterpene production in yeast. Biotechnol. Biofuels 2017, 10, 1-16. [CrossRef]

85. Ahmed, M.S.; Ikram, S.; Rasool, A.; Li, C. Design and construction of short synthetic terminators for $\beta$-amyrin production in Saccharomyces cerevisiae. Biochem. Eng. J. 2019, 146, 105-116. [CrossRef]

86. Gruchattka, E.; Hädicke, O.; Klamt, S.; Schütz, V.; Kayser, O. In silico profiling of Escherichia coli and Saccharomyces cerevisiae as terpenoid factories. Microb. Cell Factories 2013, 12, 84. [CrossRef] 
87. Cunha, J.T.; Soares, P.O.; Romaní, A.; Thevelein, J.M.; Domingues, L. Xylose fermentation efficiency of industrial Saccharomyces cerevisiae yeast with separate or combined xylose reductase/xylitol dehydrogenase and xylose isomerase pathways. Biotechnol. Biofuels 2019, 12, 20. [CrossRef] [PubMed]

88. Fischer, M.J.C.; Meyer, S.; Claudel, P.; Bergdoll, M.; Karst, F. Metabolic engineering of monoterpene synthesis in yeast. Biotechnol. Bioeng. 2011, 108, 1883-1892. [CrossRef] [PubMed]

89. Tokuhiro, K.; Muramatsu, M.; Ohto, C.; Kawaguchi, T.; Obata, S.; Muramoto, N.; Hirai, M.; Takahashi, H.; Kondo, A.; Sakuradani, E.; et al. Overproduction of Geranylgeraniol by Metabolically Engineered Saccharomyces cerevisiae. Appl. Environ. Microbiol. 2009, 75, 5536-5543. [CrossRef] [PubMed]

90. Zhou, K.; Qiao, K.; Edgar, S.M.; Stephanopoulos, G. Distributing a metabolic pathway among a microbial consortium enhances production of natural products. Nat. Biotechnol. 2015, 33, 377-383. [CrossRef] [PubMed]

91. Zhao, S.; Zhao, X.; Zou, H.; Fu, J.; Du, G.; Zhou, J.; Chen, J. Comparative proteomic analysis of Saccharomyces cerevisiae under different nitrogen sources. J. Proteom. 2014, 101, 102-112. [CrossRef]

92. Ter Schure, E. The role of ammonia metabolism in nitrogen catabolite repression in Saccharomyces cerevisiae. FEMS Microbiol. Rev. 2000, 24, 67-83. [CrossRef]

93. Torija, M.J.; Beltran, G.; Novo, M.; Poblet, M.; Rozès, N.; Guillamón, J.M.; Mas, A. Effect of the nitrogen source on the fatty acid composition of Saccharomyces cerevisiae. Food Microbiol. 2003, 20, 255-258. [CrossRef]

94. Shang, F.; Wen, S.; Wang, X.; Tan, T. Effect of nitrogen limitation on the ergosterol production by fed-batch culture of Saccharomyces cerevisiae. J. Biotechnol. 2006, 122, 285-292. [CrossRef] [PubMed]

95. Sandoval, C.M.; Ayson, M.; Moss, N.; Lieu, B.; Jackson, P.; Gaucher, S.P.; Horning, T.; Dahl, R.H.; Denery, J.R.; Abbott, D.A.; et al. Use of pantothenate as a metabolic switch increases the genetic stability of farnesene producing Saccharomyces cerevisiae. Metab. Eng. 2014, 25, 215-226. [CrossRef] [PubMed]

96. Martínez-Moreno, R.; Morales, P.; Gonzalez, R.; Mas, A.; Beltran, G. Biomass production and alcoholic fermentation performance of Saccharomyces cerevisiae as a function of nitrogen source. FEMS Yeast Res. 2012, 12, 477-485. [CrossRef]

97. Vendramini, C.; Beltran, G.; Nadai, C.; Giacomini, A.; Mas, A.; Corich, V. The role of nitrogen uptake on the competition ability of three vineyard Saccharomyces cerevisiae strains. Int. J. Food Microbiol. 2017, 258, 1-11. [CrossRef] [PubMed]

98. Narendranath, N.V.; Power, R. Relationship between pH and Medium Dissolved Solids in Terms of Growth and Metabolism of Lactobacilli and Saccharomyces cerevisiae during Ethanol Production. Appl. Environ. Microbiol. 2005, 71, 2239-2243. [CrossRef] [PubMed]

99. Jäger, S.; Trojan, H.; Kopp, T.; Laszczyk, M.N.; Scheffler, A. Pentacyclic Triterpene Distribution in Various Plants-Rich Sources for a New Group of Multi-Potent Plant Extracts. Molecules 2009, 14, 2016-2031. [CrossRef] [PubMed]

100. Muramatsu, M.; Ohto, C.; Obata, S.; Sakuradani, E.; Shimizu, S. Alkaline pH enhances farnesol production by Saccharomyces cerevisiae. J. Biosci. Bioeng. 2009, 108, 52-55. [CrossRef]

101. Chen, H.; Li, M.; Liu, C.; Zhang, H.; Xian, M.; Liu, H. Enhancement of the catalytic activity of Isopentenyl diphosphate isomerase (IDI) from Saccharomyces cerevisiae through random and site-directed mutagenesis. Microb. Cell Factories 2018, 17, 1-14. [CrossRef]

102. Torija, M.J. Effects of fermentation temperature on the strain population of Saccharomyces cerevisiae. Int. J. Food Microbiol. 2003, 80, 47-53. [CrossRef]

103. Zabed, H.; Faruq, G.; Sahu, J.N.; Azirun, M.S.; Hashim, R.; Boyce, A.N. Bioethanol Production from Fermentable Sugar Juice. Sci. World J. 2014, 2014, 1-11. [CrossRef]

104. Aguiar, T.Q.; Santos, S.B.; Martins, I.M.; Domingues, L.; Oliveira, C. Production and Bioengineering of Recombinant Pharmaceuticals. In Proteins: Sustainable Source, Processing and Applications; Elsevier: London, UK, 2019; pp. 259-293. [CrossRef]

105. Oliveira, C.; Teixeira, J.A.; Domingues, L. Recombinant production of plant lectins in microbial systems for biomedical application-The frutalin case study. Front. Plant. Sci. 2014, 5. [CrossRef] [PubMed]

106. Tan, T.; Zhang, M.; Gao, H. Ergosterol production by fed-batch fermentation of Saccharomyces cerevisiae. Enzym. Microb. Technol. 2003, 33, 366-370. [CrossRef]

107. Belo, I.; Pinheiro, R.; Mota, M. Morphological and physiological changes in Saccharomyces cerevisiae by oxidative stress from hyperbaric air. J. Biotechnol. 2005, 115, 397-404. [CrossRef] [PubMed]

108. Mesquita, T.J.B.; Sargo, C.R.; Fuzer, J.R.; Paredes, S.A.H.; Giordano, R.D.C.; Horta, A.C.L.; Zangirolami, T.C. Metabolic fluxesoriented control of bioreactors: A novel approach to tune micro-aeration and substrate feeding in fermentations. Microb. Cell Factories 2019, 18, 1-17. [CrossRef]

109. Ni, J.; Zhang, G.; Qin, L.; Li, J.; Li, C. Simultaneously down-regulation of multiplex branch pathways using CRISPRi and fermentation optimization for enhancing $\beta$-amyrin production in Saccharomyces cerevisiae. Synth. Syst. Biotechnol. 2019, 4, 79-85. [CrossRef] [PubMed]

110. Mantzouridou, F.; Naziri, E.; Tsimidou, M.Z. Squalene versus Ergosterol Formation Using Saccharomyces cerevisiae: Combined Effect of Oxygen Supply, Inoculum Size, and Fermentation Time on Yield and Selectivity of the Bioprocess. J. Agric. Food Chem. 2009, 57, 6189-6198. [CrossRef] [PubMed]

111. Ding, M.-Z.; Tian, H.-C.; Cheng, J.-S.; Yuan, Y.-J. Inoculum size-dependent interactive regulation of metabolism and stress response of Saccharomyces cerevisiae revealed by comparative metabolomics. J. Biotechnol. 2009, 144, 279-286. [CrossRef] 
112. Sood, S.; Singhal, R.; Bhat, S.; Kumar, A. Inoculum Preparation. In Comprehensive Biotechnology; Elsevier: Amsterdam, The Netherlands, 2011; pp. 151-164.

113. Stanbury, P.F.; Whitaker, A.; Hall, S.J. Culture preservation and inoculum development. In Principles of Fermentation Technology; Elsevier: Oxford, UK, 2017; pp. 335-399.

114. Subramaniam, R. High-density Cultivation in the Production of Microbial Products. Chem. Biochem. Eng. Q. 2019, 32, 451-464. [CrossRef]

115. Song, C.W.; Park, J.M.; Chung, S.C.; Lee, S.Y.; Song, H. Microbial production of 2,3-butanediol for industrial applications. J. Ind. Microbiol. Biotechnol. 2019, 46, 1583-1601. [CrossRef] [PubMed]

116. Esmaeili, A.; Rohany, S.; Safaiyan, S. Biotransformation of citral by free and immobilized Saccharomyces cerevisiae. Chem. Nat. Compd. 2012, 48, 322-324. [CrossRef]

117. Khor, G.K.; Uzir, M.H. Saccharomyces cerevisiae: A potential stereospecific reduction tool for biotransformation of mono- and sesquiterpenoids. Yeast 2010, 28, 93-107. [CrossRef] [PubMed]

118. Saarela, U.; Leiviskä, K.; Juuso, E. Modelling of a fed-batch fermentation process. Most 2003, 21, 1-23.

119. Gunther, J.; Seborg, D.; Baclaski, J. Fault detection and diagnosis in industrial fed-batch fermentation. In Proceedings of the 2006 American Control Conference, Minneapolis, MN, USA, 14-16 June 2006; Volume 2006. [CrossRef]

120. Ebert, B.E.; Czarnotta, E.; Blank, L.M. Physiologic and metabolic characterization of Saccharomyces cerevisiae reveals limitations in the synthesis of the triterpene squalene. FEMS Yeast Res. 2018, 18, 8. [CrossRef] [PubMed] 